\title{
Pharmacological Chaperones for the Treatment of $\alpha$-Mannosidosis
}

Rocío Rísquez-Cuadro, ${ }^{\dagger, \#}$ Reimi Matsumoto, ${ }^{\ddagger, \#}$ Fernando Ortega-Caballero, ${ }^{\dagger}$ Eiji Nanba, ${ }^{\ddagger}$ Katsumi Higaki, ${ }^{*, \ddagger}$ José Manuel García Fernández, ${ }^{*, \S}$ Carmen Ortiz Mellet ${ }^{*}{ }^{\dagger}$

${ }^{\dagger}$ Department of Organic Chemistry, Faculty of Chemistry, University of Sevilla, C/ Profesor García González 1, 41012 Sevilla, Spain.

${ }^{\ddagger}$ Organization for Research Initiative and Promotion, Tottori University, 86 Nishi-cho, Yonago 683-8503, Japan

§Instituto de Investigaciones Químicas (IIQ), CSIC - Universidad de Sevilla, Avda. Américo Vespucio 49, Isla de la Cartuja, 41092 Sevilla, Spain

\section{Abstract}

$\alpha$-Mannosidosis (AM) results from deficient lysosomal $\alpha$-mannosidase (LAMAN) activity and subsequent substrate accumulation in the lysosome, leading to severe pathology. Many of the AM causative mutations compromise enzyme folding and could be rescue with purposedesigned pharmacological chaperones (PCs). We found that PCs combining a LAMAN glyconebinding motif based on the $5 \mathrm{~N}, 6 \mathrm{O}$-oxomethylidenemannonojirimycin (OMJ) glycomimetic core and different aglycones, in either mono or multivalent displays, elicit binding modes involving glycone and nonglycone enzyme regions that reinforce the protein folding and stabilization potential. Multivalent derivatives exhibited potent enzyme inhibition that generally prevailed over the chaperone effect. On the contrary, monovalent OMJ derivatives with LAMAN aglycone binding area-fitting substituents proved effective as activity enhancers for several mutant LAMAN forms in AM patient fibroblasts and/or transfected MAN2B1-KO cells. This translated into a significant improvement in endosomal/lysosomal function, reverting not only the primary LAMAN substrate accumulation but also the additional downstream consequences such as cholesterol accumulation. 


\section{Introduction}

Lysosomal $\alpha$-mannosidase (LAMAN, EC 3.2.1.24) is an exo-glycosidase that hydrolyses $\alpha(1 \rightarrow 2)$, $\alpha(1 \rightarrow 3)$ and $\alpha(1 \rightarrow 6)$ mannosidic linkages as part of the sequential degradation of highmannose, hybrid and complex oligosaccharides required for the catabolism of $\mathrm{N}$-linked glycoproteins. The deficiency of this enzyme, resulting from mutations in the MAN2B1 gene, causes the rare autosomal recessive disorder $\alpha$-mannosidosis (AM; OMIM \#248500), characterized by a multisystemic accumulation of mannose-reach oligosaccharides in all tissues, resulting in compromised cellular function and apoptosis. ${ }^{1-3}$ Elevated urinary excretion of mannose-rich oligosaccharides is suggestive of the underlying enzymatic defect, although not diagnostic. ${ }^{4,5} \mathrm{AM}$ is a progressive disease: the children often born normal and their condition worsens with age, with the appearance of neurological, immunological and skeletal manifestations. A wide range of clinical phenotypes with varying degrees of severity can occur that were traditionally classified in two groups: a severe infantile phenotype (type 1 AM), which involves rapid mental deterioration, hepatosplenomegaly, severe dystosis multiplex and, often, death before the age of 3-8 years, and a mild phenotype (type $2 \mathrm{AM}$ ) featuring normal early development followed by moderate mental retardation, hear loss and milder dystosis in childhood and survival well in adult life. ${ }^{6}$ More recently, expanding the AM phenotype designation to three clinical types has been suggested, namely a mild form, clinically recognized after 10 years of age, with no skeletal abnormalities and slow progression (type 1), a moderate form with skeletal abnormalities identified before 10 years of age and ataxia at age 20-30 (type 2), and a severe form (type 3) immediately recognized and with obvious progression, leading to early death due to primary central nervous system (CNS) involvement. ${ }^{7}$ Currently, there is no satisfactory therapy for any of the AM clinical types. Hematopoietic stem cell transplantation (HCT) can partially preserve neurocognitive function, stabilize skeletal abnormalities and prevent early death, but the morbidity and mortality associated with HCT must be balanced. ${ }^{8}$ Lamzede (Velmanase alfa), a recombinant human 
LAMAN (rhLAMAN), got a positive marketing authorization recommendation by the European Medicines Agency (EMA) in January 2018 for long-term enzyme replacement therapy (ERT) of patients with moderate forms of AM. ERT has proven beneficial and is currently available for several lysosomal storage disorders (LSDs). ${ }^{9}$ In the case of AM, Phase I-III studies and long-term follow-up provided evidence of the positive clinical effect and safety of rhLAMAN. ${ }^{10,11}$ However, as all other lysosomal enzymes so far approved for ERT, it does not cross the bloodbrain barrier (BBB) and it is not indicated for neurological involvement, since its efficacy in cognitive function was not proved.

Given that a considerable number of the AM-related mutant forms of LAMAN fail to fold correctly in the endoplasmic reticulum (ER) and reach the lysosome ${ }^{12}$ the use of pharmacological chaperones (PCs) to stabilize the folding conformation, restoring trafficking and inducing functional recovery is an appealing therapeutic option. ${ }^{13-17}$ Pharmacological chaperone therapy (PCT) is under investigation for several LSDs ${ }^{18-23}$ and has already been approved for Fabry disease. ${ }^{24-26}$ Although non-inhibitory PCs would be preferable, with few exceptions $^{27-30}$ PCs for LSDs are competitive inhibitors of the target enzyme that behave as enhancers when used at subinhibitory concentrations. ${ }^{31}$ Depending on their structure, PCs can cross the BBB and are therefore suitable for the treatment of LSDs affecting the CNS. ${ }^{32}$ Notwithstanding, at present there are no studies addressing the possibility of using PCs for the therapy of AM. The reasons are probably manifold. First, LAMAM belongs to the class II $\alpha-$ mannosidases, annotated in the glycosyl hydrolase family GH38 in the CAZy classification. ${ }^{33}$ In this glycosidase family the active site is located in a relatively wide and open cleft at the protein surface, ${ }^{34}$ which likely makes less probable that binding of an active-site directed PC can force correct mutant protein folding. Second, the most broadly studied naturally occurring LAMAN competitive inhibitor, the indolizidine-type iminosugar swainsonine (Figure 1), is a lysosomotropic compound that accumulates rapidly in the lysosomes of normal cells, resulting in a phenocopy of genetic AM; consequently, its administration would aggravate the condition 
in AM patients. ${ }^{35}$ Moreover, swainsonine simultaneously inhibits Golgi $\alpha$-mannosidase II and the reported chemical modifications of the natural compound generally decrease the selectivity towards LAMAN in favor of the Golgi enzyme. ${ }^{36,37}$ The same holds true for the fivemembered carbocyclic inhibitor mannostatin A (Figure 1) and polyhydroxylated pyrrolidine alkaloids. ${ }^{38,39}$ Third, whereas polyhydroxylated piperidine-type iminosugar derivatives are generally good chaperone candidates for lysosomal enzymes with a matching configurational specificity, ${ }^{18}$ the related manno-configured representative 1-deoxymannonojirimycin (DMJ) does not bind LAMAN; it is instead an inhibitor of the ER $\alpha$-mannosidase I and Golgi $\alpha$ mannosidase $\mathrm{I}^{40}$ The neutral bicyclic analogue $5 \mathrm{~N}, 6 \mathrm{O}$-oxomethylidenemannonojirimycin $(\mathrm{OMJ}){ }^{41}$ a member of the $\mathrm{sp}^{2}$-iminosugar glycomimetic family (i.e., sugar look-alikes possessing a pseudoamide-type nitrogen atom, with a high $\mathrm{sp}^{2}$-hybridation character, at the position of the endocyclic oxygen in monosaccharides), ${ }^{42}$ likewise failed to inhibit class II GH38 $\alpha$ mannosidases. In stark contrast, the gem-diamine derivative OMJ-1- $\mathrm{NH}_{2}$ and the $\mathrm{N}$-octyl glycoside analogue $\mathbf{1}$ (Figure 1) were found to behave as potent inhibitors of Jack bean vacuolar GH38 $\alpha$-mannosidase, which shares a similar active site architecture with the human lysosomal enzyme. ${ }^{43,44}$ The possibility to install aglycone-type substituents at the pseudoanomeric position offers the opportunity to promote additional interactions with regions of the enzyme beyond the glycone site (i.e., the site where the terminal mannosyl unit that is going to be detached from the substrate locates), ${ }^{45}$ which might contribute to stabilize the correct folding in AM-causative mutant LAMAN variants. Multimeric derivatives represent a supplementary option for this endeavor, since GH38 $\alpha$-mannosidases are archetypic examples of multivalency-responsive glycosidases. ${ }^{46-49} \mathrm{~A}$ risk remains, however, that the multipoint binding mode operating in these cases $^{50-52}$ will affect negatively the LAMAN trafficking and maturation process along the secretory pathway ${ }^{2,12}$ and/or the enzymeinhibitor dissociation rate in the lysosome, thwarting any medical benefit. ${ }^{18}$ To address these questions, we have now conducted a study of the inhibitory/chaperoning abilities of 
monovalent versus multivalent gem-diamine OMJ conjugates and report here the synthetic, enzymological and cell assay results. The data highlight the importance of carefully modulating aglycone and multivalent interactions in a mutation-dependent basis for chaperone optimization and provide a proof of concept of the potential of OMJ-based PCT to become an alternative to ERT for $\alpha$-mannosidosis.

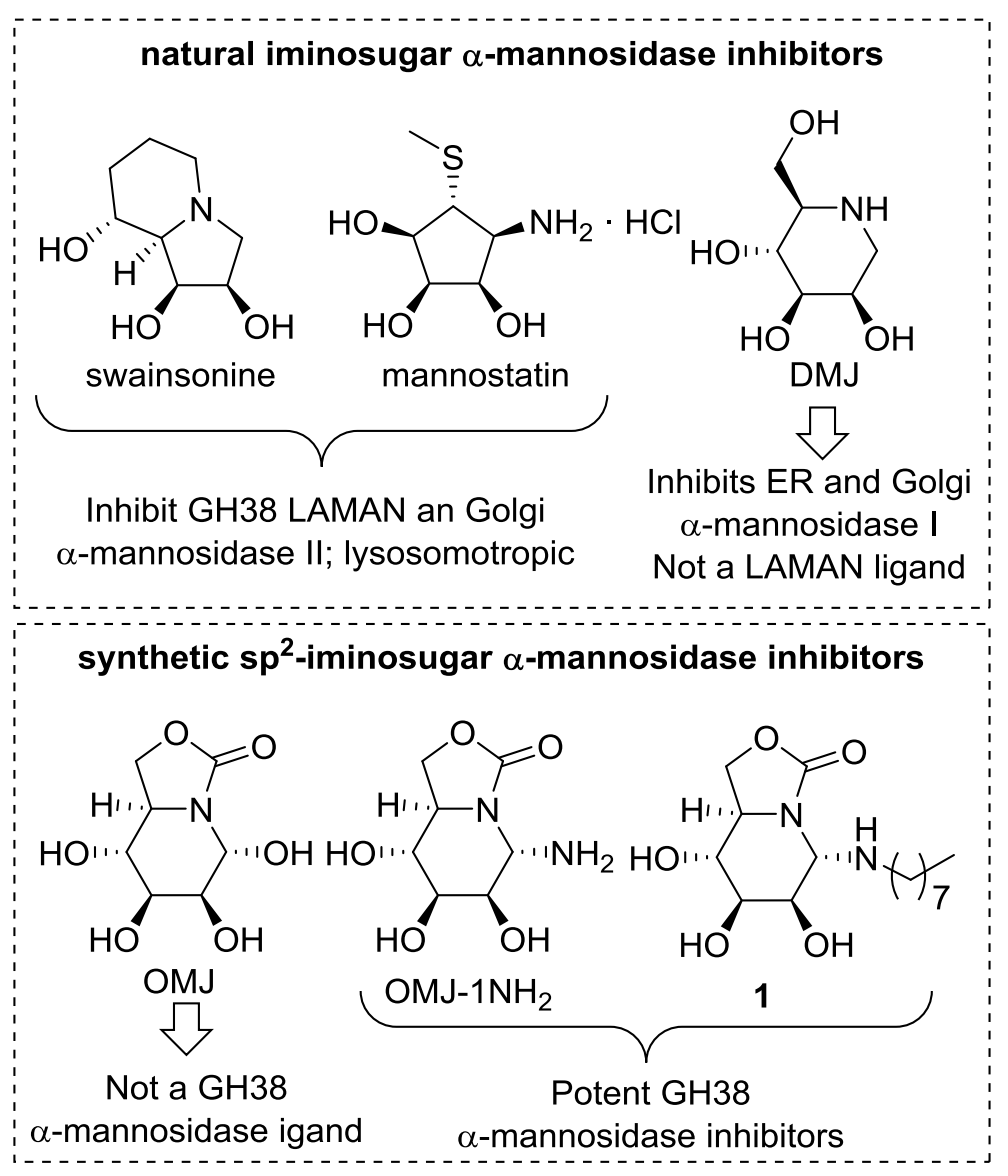

Figure 1. Structures of representative naturally occurring iminosugar (swainsonine, mannostatin, DMJ) and synthetic sp²-iminosugar (OMJ derivatives) mannosidase inhibitors.

\section{Results and Discussion}

Candidate Selection Rational and Synthesis. The presence of the aliphatic aglycone in the $\mathrm{sp}^{2}$ iminosugar $\mathrm{N}$-octyl glycoside $\mathbf{1}$ leads to an over $\mathbf{2}$-fold increase in the inhibitory potency (i.e., an over 2 -fold decrease in the inhibition constant) towards Jack bean $\alpha$-mannosidase $\left(K_{\mathrm{i}}=3.2\right.$ 
$\pm 0.4 \mu \mathrm{M})^{44}$ as compared with the unsubstituted gem-diamine reference OMJ-1- $\mathrm{NH}_{2}\left(K_{\mathrm{i}}=7.0 \pm\right.$ $1 \mu \mathrm{M}) \cdot{ }^{43} \mathrm{~N}$-alkyl substitution further improved dramatically the $\alpha$-mannosidase selectivity: whereas OMJ-1- $\mathrm{NH}_{2}$ also inhibited $\beta$-glucosidase (almods and bovine liver) and $\beta$-mannosidase (Helix pomatia) with $K_{\mathrm{i}}$ values in the $20-200 \mu \mathrm{M}$ range, ${ }^{43}$ compound 1 exhibited total anomeric selectivity (no inhibition of $\beta$-mannosidase) and inhibited the mammalian $\beta$-glucosidase $\left(K_{\mathrm{i}}=\right.$ $260 \pm 26 \mu \mathrm{M}$ ) almost two-orders-of magnitude weaker than plant GH38 $\alpha$-mannosidase. ${ }^{44} \mathrm{We}$ therefore included $\mathbf{1}$ as a first candidate in our screening for human LAMAN chaperones. The monovalent OMJ $\mathrm{N}$-glycoside series was broadened with amphiphilic derivatives equipped with diverse functionalities at the aglycone: the OMJ $N$-( $\omega$-azido)hexyl and nonyl glycosides 2 and $3^{, 52}$ and the $\mathrm{N}$-[9-(tert-butoxycarbonyl)amino]nonyl derivative $\mathbf{4}$. In principle, 2-4 are appropriate precursors for multiple coupling reactions through "click"-type methodologies, either directly or after elaboration. The 6-(4-propyl-1,2,3-triazol-1-yl)hexyl glycoside $5^{52}$ was indeed conceived as a monovalent control for multivalent click conjugates accessible by copper(I)-catalyzed azide-alkyne coupling (CuAAC) with alkyne-functionalized partners: it contains a single OMJ motif plus the hexylene and triazolyl fragments that will be displayed in several copies in the multivalent conjugates. We keep in mind that triazole rings have been previously found to preserve the recognition abilities of oligosaccharide mimetics towards receptors and enzymes, behaving as monosaccharide surrogates..$^{53}$ For the purpose of this study, we have chosen $\beta$-cyclodextrin $(\beta C D)$ as a platform for multivalency generation because of its biocompatibility and amenability to regioselective chemical functionalization. ${ }^{54}$ The 6 monosubstituted $\beta C D$ conjugate 6 was designed to duly probe the impact of the $\beta C D$ macroring in the enzyme binding capabilities. The collection of OMJ $\mathrm{N}$-glycosides was completed with the homohepta conjugate $\mathbf{7}$ and the statistic heteroconjugates $\mathbf{8}$ and $\mathbf{9}$, incorporating OMJ and $\alpha$-mannopyranosyl motifs in 1:1 ratio. Whereas 7 will provide information on the impact of multivalency in the inhibitory/chaperoning properties towards $\alpha$ mannosidase, compounds $\mathbf{8}$ and $\mathbf{9}$ were conceived to assess potential positive or negative 
synergistic effects when inhibitory and glycosidic motifs are exposed together, an intriguing phenomenon recently observed in multivalent enzyme inhibition. ${ }^{55}$ The homogeneous tetradecavalent OMJ- $\beta C D$ conjugate 10 , was also prepared and included in the initial screening against a panel of commercial glycosidases comprising Jack bean $\alpha$-mannosidase, as a relevant tool for GH38 $\alpha$-mannosidase ligand selection, as well as enzymes with $\alpha$-glucosidase, $\beta$ glucosidase, $\alpha$-galactosidase, $\beta$-galactosidase and $\beta$-mannosidase activities. The corresponding $K_{\mathrm{i}}$ values, obtained using the isolated enzymes after Lineweaver-Burk plots, are collected in Table S1 in the SI. Whereas 2-9 behaved as strong competitive inhibitors of $\alpha$-mannosidase ( $K_{\mathrm{i}}$ values in the $0.5-50 \mu \mathrm{M}$ range) and exhibited high selectivity (modest inhibition of bovine liver $\beta$-glucosidase, with $K_{\mathrm{i}}$ values in the $140-300 \mu \mathrm{M}$ range, and no detectable inhibition of any of the other tested enzymes at concentrations up to $2 \mathrm{mM}$ ), compound $\mathbf{1 0}$ showed considerable promiscuity in this assay and was not pursued further for studies against human enzymes.

It should be stressed that control experiments were first performed with the heterovalent clusters 8 and $\mathbf{9}$ to check the susceptibility of the mannosyl moieties at the periphery towards enzymatic cleavage. No free mannose could be detected (gas chromatography monitoring; see the SI for experimental details) after incubation with the commercial GH38 enzyme used in this study under identical conditions to those employed for glycosidase inhibition assays, even for much longer incubation times $(4 \mathrm{~h})$. This is a someway surprising observation that has also been reported for the GH38 a-mannosidase from Jack bean when faced to other multivalent presentations of $\alpha$-mannoside motifs. It likely reflects the inability of the peripheral mannosides to adopt the right orientation in the catalytic site due to steric constrains. ${ }^{56,57}$ Alterations in substrate hydrolysis kinetics in the presence of $\mathbf{8}$ or $\mathbf{9}$ must then be ascribed to interactions with the enzyme but not to substrate-like behavior. 

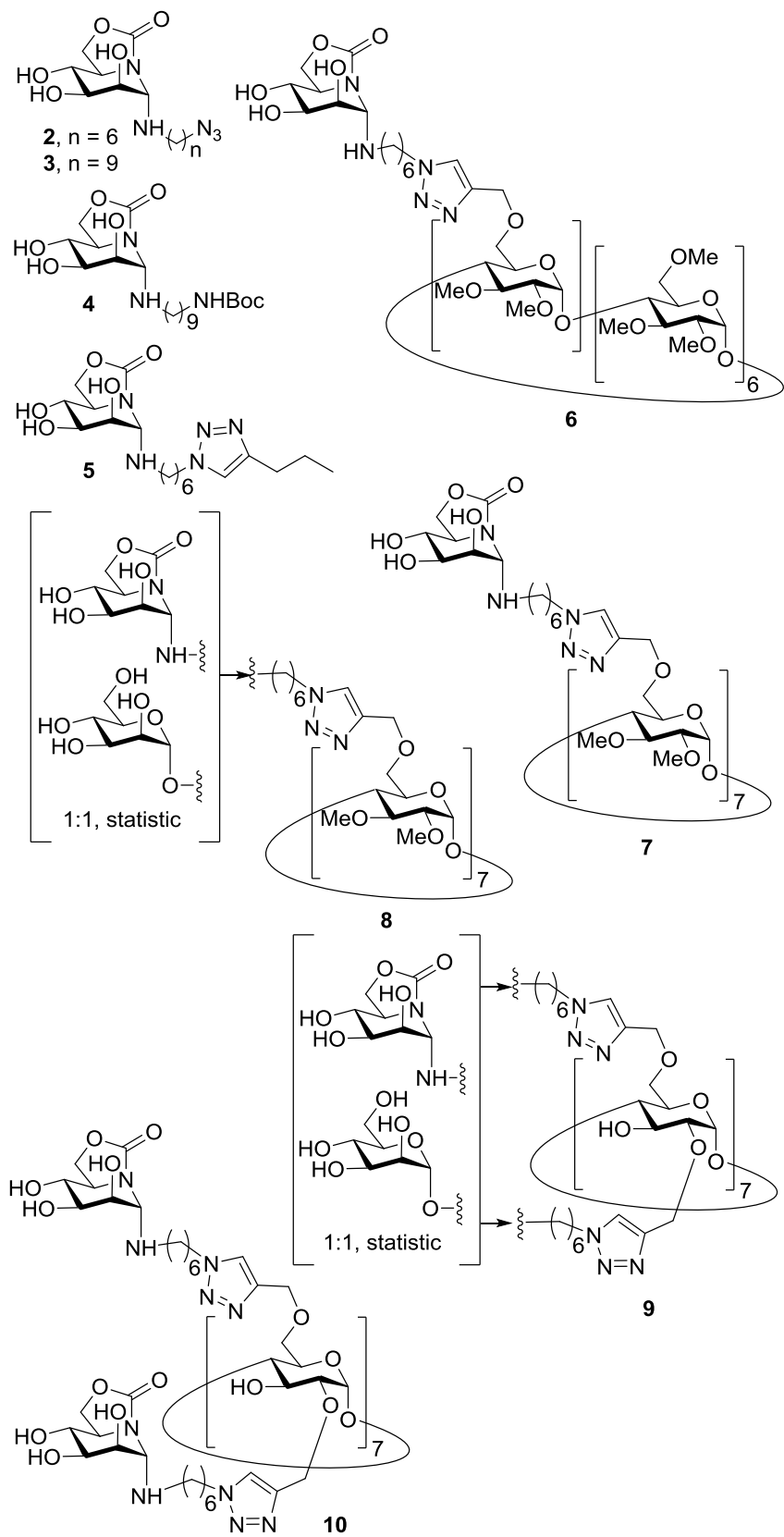

Figure 2. Structures of the monovalent (2-6; in addition to 1) and multivalent (7-10) OMJ Nglycosides included in the present study.

Compounds 2-5 were synthesized following the previously reported procedures..$^{52}$ Briefly, incubation of the hemiaminal precursor OMJ with mono-Boc-protected alkylenediamines afforded the corresponding gem-diamine adducts that were transformed into the terminal azidoalkyl $\mathrm{N}$-glycoside derivatives after hydrolysis of the carbamate protecting group and azido-transfer reaction of the resulting amines with trifluromethanesulfonyl azide (triflyl azide; 
$\left.\mathrm{TfN}_{3}\right)$. CuAAC clicking of 2 with 1-pentine then affords the monovalent 4-propyltriazol-1-yl conjugate 5 . The same clicking procedure was employed to access the new mono- and hepta(O-6)- $\beta C D / O M J$ conjugates 6 and 7 or the tetradeca-(O-2,O-6)- $\beta C D / O M J$ derivative $\mathbf{1 0}$, entailing the corresponding mono-, hepta- or tetradeca-O-propargyl $\beta C D$ ethers (11-13, respectively) as the alkyne partners. The OMJ/ $\alpha$-D-mannopyranosyl heterovalent analogues 8 and 9 were obtained by conducting the CuAAC multiconjugation reaction of the polypropargylated $C D$ derivatives with an equimolecular mixture of OMJ and 6-azidohexyl $\alpha$-Dmannopyranoside (14) under identical conditions (co-clicking). The structure of all the adducts was confirmed by NMR and mass spectrometry (Scheme 1). The chemical stability of the gemdiamine functionality in the fully unprotected derivatives was additionally assessed by ${ }^{1} \mathrm{H}$ NMR in the 1-to- $12 \mathrm{pH}$ range.

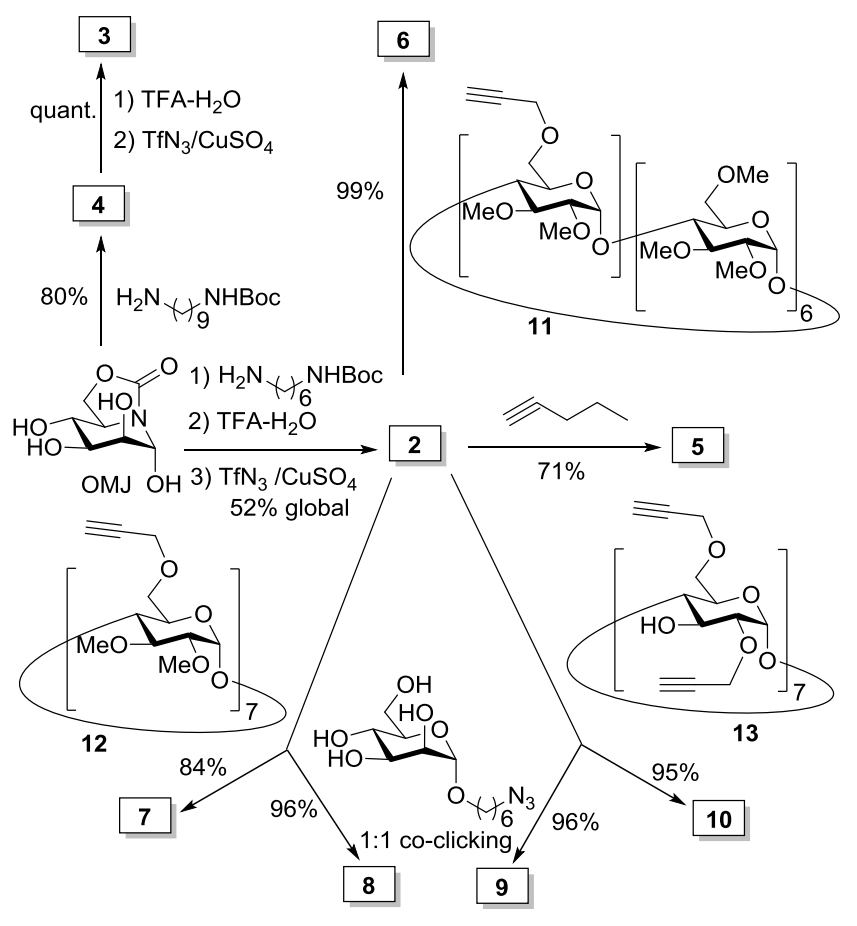

Scheme 1. Synthesis of compounds 2-10.

Inhibition of Human $\alpha$-Mannosidase: Aglycone and Multivalent Effects. The inhibitory properties of the selected candidates 1-9 against human $\alpha$-mannosidase were determined in 
cell lysates using 4-methylumbelliferone $\alpha$-D-mannopyranoside as a reporter substrate (Figure 3). Monovalent OMJ $\mathrm{N}$-glycosides $\mathbf{1 ,} 3$ and 4, bearing $\mathrm{C}_{8}$ or $\mathrm{C}_{9}$ hydrophobic aglycones, showed similar $\mathrm{IC}_{50}$ values, in the $19-31 \mu \mathrm{M}$ range. The 6-azidohexyl derivative $\mathbf{2}$, a homologue of $\mathbf{3}$ with a $C_{6}$ aglycone chain, was a significantly weaker inhibitor in this assay $\left(I_{50} 116 \mu \mathrm{M}\right)$. Yet, the corresponding "clicked" product 5 recovered the inhibition capacity towards human $\alpha$ mannosidase ( $\left(\mathrm{C}_{50} 17.3 \mu \mathrm{M}\right)$ and the presence of the $\beta C D$ scaffold in the aglycone moiety of 6 further boosted the inhibition potency by one order of magnitude $\left(\mathrm{IC}_{50} 2.2 \mu \mathrm{M}\right)$. It has been reported that cyclodextrins are good acceptors for the reverse action of the related GH38 $\alpha$ mannosidase from Jack bean, meaning that their macrocyclic structure fits well in the aglycone region of class II $\alpha$-mannosidases and can establish favorable interactions that reinforce enzyme-inhibitor complex stability. ${ }^{58}$ The same is valid for primary-face polymannosylated $\beta C D$ derivatives. ${ }^{59}$ Our experimental results support that even more extensive $\beta C D$ substitution profiles are favorably accommodated by the enzyme. Indeed, the homo and heterogeneous per-(0-6)- $\beta C D$ substituted derivatives $\mathbf{7}$ and $\mathbf{8}$ behaved as very strong inhibitors of human $\alpha-$ mannosidase, with $\mathrm{IC}_{50}$ values of 0.44 and $0.45 \mu \mathrm{M}$, respectively. Note that the fact that the inhibitory properties are insensitive to the replacement of OMJ motifs in 7 into $\alpha$-Dmannopyranosyl units in $\mathbf{8}$ strongly suggests that the inhibition potency enhancement as compared with 6 is mainly due to additional non-glycone interactions that compensate the presumed sterically more hindered access of the inhibitory OMJ motif to the enzyme glycone binding spot. This is in agreement with the body of evidences supporting that (hetero)multivalent inhibitors operate through multipoint (glycone/aglycone/surface) binding modes that are radically different of those governing enzyme inhibition by monovalent species. ${ }^{46,60}$ The macromolecular hetero-14-valent conjugate $9\left(\mathrm{IC}_{50} 55 \mu \mathrm{M}\right)$ was a 100 -fold weaker inhibitor of human $\alpha$-mannosidase than the 7 -valent counterparts $\mathbf{7}$ or $\mathbf{8}$, which probably reflects a less favorable access of the OMJ units to the active site that is not overcome by favorable interactions at allosteric enzyme regions (Figure 3). 


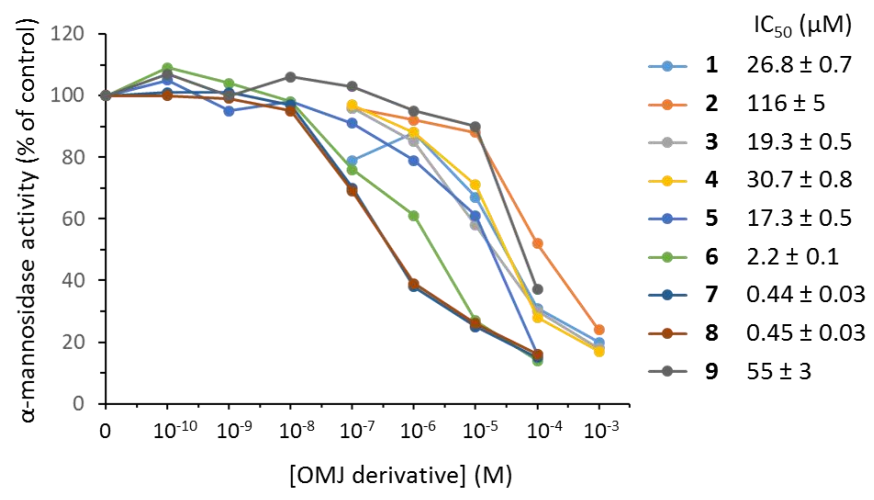

Figure 3. $\alpha$-Mannosidase inhibition plots and $\mathrm{IC}_{50}$ values ( \pm SEM) for the PC candidates 1-9 determined in wild type human fibroblast lysates. Each point represents the mean of three determinations, each done in triplicate; errors bars are omitted for the sake of clarity.

Impact of Multivalency in the $\alpha$-Mannosidase Inhibitor/Effector Character of OMJ NGlycosides in Wild Type Human Fibroblasts. The effect of compounds 1-9 in the activity of $\alpha$ mannosidase in cellulo was first probed in normal (healthy) fibroblasts. Cells were incubated with each OMJ derivative at $0.2,2.0$ and $20 \mu \mathrm{M}$ concentration for four days (found to be the optimal incubation time in terms of maximum chaperone effect and data reproducibility), then lysed and the $\alpha$-mannosidase activity determined as above. All the PCs were fully soluble under these experimental conditions. Sharply different profiles were obtained for monovalent (1-6) as compared with multivalent conjugates (7-9). Thus, the first behaved as dosedependent effectors, promoting $\alpha$-mannosidase activity increases ranging from 1.3 to 2.4 -fold (Figure 4) and relative efficiencies roughly reflecting their enzyme binding affinities, as derived from the corresponding $I \mathrm{I}_{50}$ values (see Figure 3). The triazol-equipped OMJ $\mathrm{N}$-glycosides 5 and 6 triggered the highest activity enhancements, already about 2-fold at $0.2 \mu \mathrm{M}$ and reaching the optimum at $2 \mu \mathrm{M}$ (2.4-fold, for 5) or $20 \mu \mathrm{M}$ (2.15 fold, for 6). Going down to 0.002 and 0.02 $\mu \mathrm{M}$ concentrations abolished any detectable effect in these cases. On the contrary, the homo and hetero-heptavalent representatives $\mathbf{7}$ and $\mathbf{8}$ dramatically decreased $\alpha$-mannosidase activity in the cells to values below $20 \%$ of the initial level at $0.2 \mu \mathrm{M}$ and down to $5-10 \%$ at 20 
$\mu \mathrm{M}$. Enzyme activity lessening was still evident after treatment of the fibroblasts with a $20 \mathrm{nM}$ concentration of the compounds and, in the case of 7, even at $2 \mathrm{nM}$. The hetero-14-valent derivative 9 exhibited a mixed inhibitor/effector trend: it provoked a $20 \%$ enhancement in enzyme activity at $0.2 \mu \mathrm{M}$ but lower or higher concentrations both had a deleterious effect in $\alpha$-mannosidase performance (Figure 4).

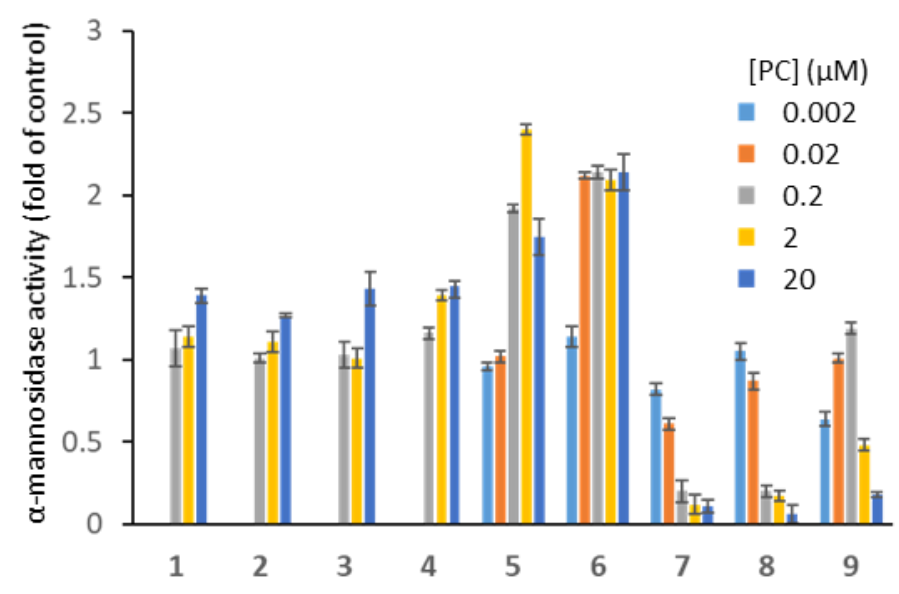

Figure 4. Effect of increasing concentrations of the PC candidates 1-9 on the activity of $\alpha$ mannosidase in human wild type fibroblasts after $4 \mathrm{~d}$ incubation. Each bar represents the mean \pm SEM of three determinations each done in triplicate.

The abrupt shift from an enhancing to a disrupting effect in the $\alpha$-mannosidase activity elicited by multivalency cannot be rationalized exclusively on the basis of the observed increment in human $\alpha$-mannosidase inhibition potency determined in the cell lysate assay. For instance, compounds 7 and 8 decreased $\alpha$-mannosidase activity to $60 \%$ relative to the control at $0.2 \mu \mathrm{M}$ in fibroblast lysates, according to the corresponding inhibition plots (Figure 3), but the activity further dropped down to $20 \%$ in the living cells after the $4 \mathrm{~d}$ incubation period (Figure 4). Even more shocking, compound 9 , a relatively modest $\alpha$-mannosidase inhibitor $\left(\mathrm{IC}_{50} 55 \mu \mathrm{M}\right)$, provoked a strong reduction in $\alpha$-mannosidase activity (to $65 \%$ that of the control) at $2 \mathrm{nM}$ concentration in the fibroblasts. The data can be concealed assuming that OMJ derivatives influence the overall $\alpha$-mannosidase activity in the fibroblasts by at least three distinct 
mechanisms: (a) binding to LAMAN in the ER, favoring its correct folding and trafficking and simultaneously improving enzyme stability and lysosomal turnover (chaperone effect); (b) competing with the substrate for the LAMAN active site, eventually impairing substrate processing (inhibitor effect); and (c) negatively interfering with LAMAN trafficking, probably by simultaneously inhibiting the ER/Golgi $\alpha$-mannosidases I and/or II involved in protein folding cycle quality control and processing, ${ }^{61}$ resulting in LAMAN being targeted for ER-associated degradation (ERAD). Whereas for active-site directed monovalent OMJ derivatives the observed $\alpha$-mannosidase activity profiles can be explained in terms of the chaperone/inhibitor balance, globally acting as enzyme effectors in the concentration range of the experiment, ERAD targeting in combination with LAMAN inhibition overpowers any possible chaperone effect in the case of the multivalent conjugates $\mathbf{7}$ and $\mathbf{8}$. Since LAMAN constitute the largest fraction of the $\alpha$-mannosidases in fibroblasts, ${ }^{62}$ the overall consequence is a drastic decrease in total $\alpha$-mannosidase activity. In the case of 9, LAMAN targeting to ERAD is also dominant at low $(\mathrm{nM})$ concentrations, as inferred from the observed $\alpha$-mannosidase activity reduction. Higher concentrations of $\mathbf{9}$ trigger an effector behavior that is cancelled by LAMAN inhibition at the highest concentration assayed $(20 \mu \mathrm{M})$. It should be pointed out, however, that differences in the membrane crossing capabilities between the monovalent and the multivalent conjugates cannot be discarded at this point; direct comparison of the inhibition/chaperoning efficiency must be thus taken with care.

Pharmacological Chaperone Evaluation in $\alpha$-Mannosidosis Fibroblasts. We next evaluated the whole series of mono and multivalent OMJ derivatives in fibroblasts from AM patients with three homozygous mutations: H72L (formerly denoted as H71L), P356R and R750W. Replacement of histidine by leucine at position 72 alters coordination of the $\mathrm{Zn}^{2+}$ cofactor in the LAMAN active site, which affects the catalytic properties of the enzyme but not transport to the lysosome. ${ }^{63}$ P356R and R750W are examples of mutations leading to misfolded and ERretained enzymes: P356R is located in the catalytic domain whereas R750W is in a domain 
interface significantly more distant from the active site area. ${ }^{63}$ The latter missense mutation is the most common AM-associated sequence variant and accounts for approximately $28 \%$ of the reported disease alleles. The residual total $\alpha$-mannosidase activity in these patient fibroblasts was found to be 20,15 and $25 \%$ relative to the wild type fibroblast control, respectively, which is consistent with previous reports. ${ }^{34,63}$ It must be pointed out, however, that $\alpha$-mannosidases other than LAMAN, such as Golgi $\alpha$-mannosidase II, also are active in this assay. The specific LAMAN activities in a broad series of AM patient fibroblasts, including those used in this study, have been previously determined after immunoprecipitation with antibodies against native human LAMAN and found to be much lower, in the range $0.3-1.3 \%$ that in the control, irrespective of the mildness or severity of the phenotype. Although both environmental and other genetic factors may contribute, the large variations in clinical expression for such a short interval of residual activity values suggests that even very small enhancements in LAMAN residual activity can have a strong impact in disease condition. For chaperone activity normalization purposes, an average residual activity of $0.8 \%$ that of the control will be here considered.

The structurally related amphiphilic OMJ $N$-glycosides 1-4 behaved as dose-dependent enzyme effectors in H72L/H72L fibroblasts, affording LAMAN activity enhancements ranging from 7.8 to 11 fold at $20 \mu \mathrm{M}$ (Figure $5 \mathrm{~A}$ ). The monovalent triazol-containing derivatives 5 and 6 enhanced enzyme activity by 4 and 7.8 -fold when used at $0.2 \mu \mathrm{M}$, respectively, but lower or higher concentrations turned to be counterproductive. The multivalent conjugates on their side did not produced any LAMAN activity enhancement in this mutant; instead they severely depleted total $\alpha$-mannosidase activity as in wild type fibroblasts (data not shown). The exception was the hetero-14-valent compound 9, which elicited a 5.5-fold enhancement of the mutant enzyme activity when used at $2 \mathrm{nM}$. Amphiphilicity was found critical for OMJ conjugates to behave as LAMAN chaperones in P356R/P356R fibroblasts, compounds $\mathbf{1}, \mathbf{3}$ and 4 enhancing the mutant enzyme activity by $4.5-6.4$ fold at 2-20 $\mu \mathrm{M}$ (Figure $5 \mathrm{~B}$ ). The 
chaperoning efficiency of compound $\mathbf{2}$, with a shorter lipophilic aglycone, was significantly lower but still significant (3.4-fold at $20 \mu \mathrm{M})$, whereas the presence of the hydrophilic triazol ring in $\mathbf{5}$ and $\mathbf{6}$ virtually abolished any chaperone effect. The multivalent clusters 7-9 were also inactive, with the single exception of the heptavalent $\beta C D$-centered homoconjugate 8 that promoted a 6.3-fold increase in LAMAN activity when used at $0.2 \mu \mathrm{M}$. In stark contrast, the $\alpha$ mannosidose activity in fibroblasts hosting the R750W/R750W mutation, located in a noncatalytic domain, was much less sensitive to incubation with the amphiphilic OMJ $\mathrm{N}$-glycosides 1-4, with increments about 30\% (except $51 \%$ for 4 at $2 \mu \mathrm{M}$ ). In this particular mutant, the monovalent triazol-equipped adducts 5 and $\mathbf{6}$ proved more efficient as PCs, promoting a $65 \%$ activity enhancement at a 1000-fold lower concentration ( $2 \mathrm{nM})$. The multivalent conjugates 7 and 9 also showed significant R750W/R750W LAMAN activity enhancements under these conditions ( 44 and $38 \%$ at $2 \mathrm{nM}$, respectively), substantiating the hypothesis that competitive inhibitors reaching areas beyond the glycone binding receptacle, i.e., aglycone or surface binding sites, may be better pharmacological chaperone leads when targeting folding defective mutant enzymes if the mutation is remote from the catalytic site (Figure 5C).
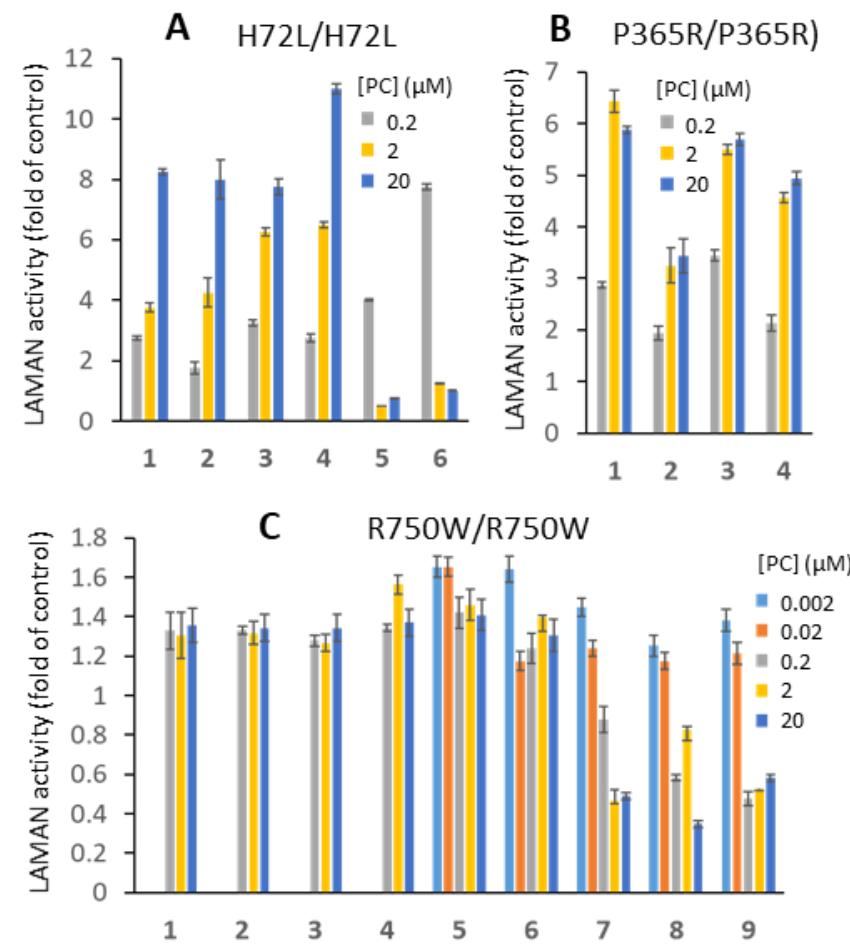
Figure 5. Chaperone activities of OMJ N-glycosides in cultured AM patients' fibroblasts bearing the LAMAN homozygous mutations H72L (A), P365R (B) and R750W (C). Compounds 7-9 were inactive in $\mathrm{H} 72 \mathrm{~L}$ fibroblasts (except 9 at $2 \mathrm{~nm}$, which leads to a 5.5-fold LAMAN activity enhancement) and compounds 5-9 were inactive in P365R fibroblasts (except 8 at $0.2 \mu \mathrm{m}$, which lead to a 6.3-fold LAMAN activity enhancement). Each bar represents the mean \pm SEM of three determinations each done in triplicate.

The responsiveness of $\mathrm{H} 72 \mathrm{~L} / \mathrm{H} 72 \mathrm{~L}$ fibroblasts, for which the LAMAN catalytic activity is compromised but folding and lysosomal localization are not affected, to pharmacological chaperoning is remarkable. Fractionation analyses of cell lysates before and after the treatment with the most efficient PC candidate 4 at $20 \mu \mathrm{M}$ confirmed that the $\alpha$-mannosidase activity is predominantly associated to the lysosomal fraction and that the chaperone promotes an above $30 \% \alpha$-mannosidase activity enhancement (Figure $6 \mathrm{~A}$ ). The ratio between the $\alpha$-mannosidase activity in the lysosomes and the ER/Golgi remains virtually unchanged, suggesting that LAMAN stabilization upon chaperone complexation increases the half-life of the enzyme and leads to a net augmentation of the total enzyme, without affecting trafficking and processing. Nevertheless, other mechanisms, e.g. the improvement of enzyme trafficking (as observed in wild type fibroblasts) or assistance in $\mathrm{Zn}$ (II) transfer to the mutant enzyme active site, could also operate. The increase of total LAMAN in fibroblasts from $\mathrm{H} 72 \mathrm{~L} / \mathrm{H} 72 \mathrm{~L}$ patients consequent to the treatment with compound $\mathbf{5}$ and, more prominently, with compound 6 at $0.2 \mu \mathrm{M}$ was also confirmed by western blot using a specific anti-LAMAN antibody (Figure 6B). Remarkably, compounds $\mathbf{4 , 5}$ and $\mathbf{6}$ were able to reduce cholesterol accumulation in $\mathrm{H} 72 \mathrm{~L} / \mathrm{H} 72 \mathrm{~L}$ cells (3-fold intracellular cholesterol content as compared with the wild type control as determined in this work), while not affecting normal cells, with relative potencies and efficiency-versus-concentration trends that paralleled their $\alpha$-mannosidase activity enhancement profiles (Figure 6C). Cholesterol is a secondary storage product in several lysosomal disorders, including AM, and a direct link between cholesterol accumulation and 
disease pathogenesis, particularly neuropathogenesis, has been suggested. ${ }^{64}$ The ensemble of data strongly support that the LAMAN activity enhancement promoted by the OMJ N-glycoside chaperones translates into a significant improvement in endosomal/lysosomal function, reverting not only the primary LAMAN substrate accumulation but also the additional downstream consequences. The significance of this result is better perceived considering that ERT using recombinant LAMAN was reported to be inefficient at decreasing cholesterol levels in AM settings. ${ }^{65}$
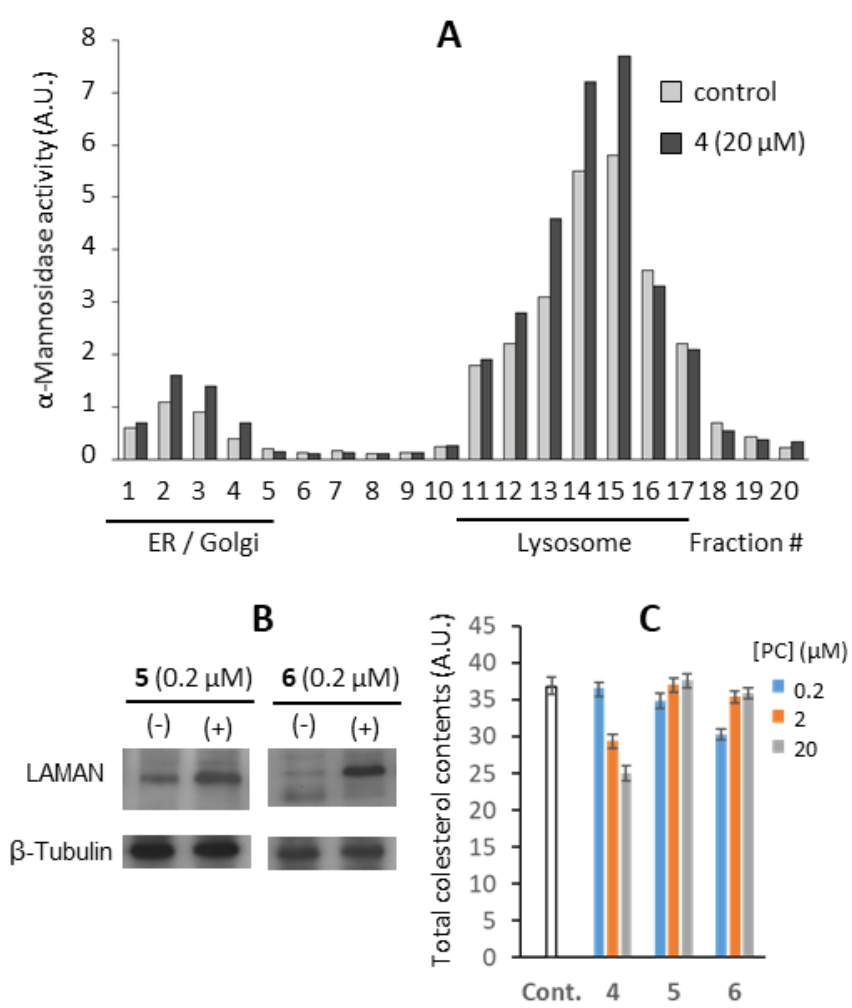

Figure 6. Effects of monovalent $\mathrm{OMJ} \mathrm{N}$-glycosides in AM patient's fibroblasts hosting the $\mathrm{H} 72 \mathrm{~L}$ LAMAN mutation in homozygosis. (A) Effect of compound $\mathbf{4}$ at $20 \mu \mathrm{M}$ in the total $\alpha$ mannosidase content in the ER/Golgi and in the lysosome as determined by cell fractionation (mean of triplicate experiments). (B) Western blot qualitative evaluation of the increase in LAMAN charge in the H72L fibroblasts after treatment with compounds 5 or 6 at $0.2 \mu \mathrm{M}$ (the optimal concentration as determined in chaperoning experiments; see Figure 5A). (C) Effect of 
compounds 4-6 in the cholesterol content of the H72L fibroblasts (each bar represents the mean \pm SEM of three determinations each done in triplicate).

Pharmacological Chaperone Evaluation in MAN2B1-KO Cells Expressing $\alpha$-MannosidosisCausative LAMAN Mutations.

The chaperone effect of the two OMJ derivatives $\mathbf{4}$ and $\mathbf{6}$, exhibiting the best effector/inhibitor balance in healthy and AM fibroblasts, was next investigated in MAN2B1-KO human nearhaploid HAP1 cells transiently transfected with five different AM-causative missense mutants: $\mathrm{H} 72 \mathrm{~L}$, which will allow comparison with the above discussed results in the corresponding patient fibroblasts, C55F and R916C as mutations located in areas close to the LAMAN binding site leading to misfolding and ER retention, and L352P and L565P as examples of mutations that also result in protein misfolding but that are located in non-catalytic domains. ${ }^{63}$ The concentrations tested were $0.2,2.0$ and $20 \mu \mathrm{M}$. The activities of at least three out of the five mutants were significantly enhanced by both $\mathbf{4}$ and 6, namely C55F, H72L and R916C. Notably, whereas the total $\alpha$-mannosidase activity enhancement promoted by the amphiphilic $\omega$-(tertbutoxycarbonylamino)nonyl derivative 4 increased with concentration, affording 111, 68 and $63 \%$ activity enhancements at $20 \mu \mathrm{M}$, respectively, the chaperone effect for the $\beta$ cyclodextrin conjugate 6 reached a maximum at the lowest concentration of $0.2 \mu \mathrm{M}(23,48$ and $45 \%$, respectively), dropping to almost basal level at the highest concentration assayed. This is consistent with the LAMAN-activity-enhancement-versus-concentration trends observed in fibroblasts hosting the same mutation. Considering that $\mathbf{4}$ is a one-order-ofmagnitude weaker inhibitor of $\alpha$-mannosidase than 6 (Figure 3) the divergent profiles probably reflect a faster chaperone/inhibitor compensation effect for the later compound. The other two mutations assessed, L352P and L565P, were only weakly responsive to the OMJ chaperones, the highest activity increases reached in this experiment being $10 \%$ for the first one (using 6 at $0.2 \mu \mathrm{M}$ ) and $14 \%$ for the second one (using 3 at $2 \mu \mathrm{M}$ ). It should be also 
considered that proline is a very rigid residue and it does not readily adopt conformations that other residues are allowed to during protein folding.

Table 1. Chaperone activities of compounds 4 and 6 in MAN21B-KO HAP1 cells with different AM-associated mutant LAMAN expression (\% of enzyme activity enhancements relative to control).

\begin{tabular}{lllllll}
\hline & \multicolumn{5}{c}{$[4](\mu \mathrm{M})$} & \multicolumn{5}{c}{$[6](\mu \mathrm{M})$} \\
\cline { 2 - 6 } & 0.2 & 2 & 20 & 0.2 & 2 & 20 \\
C55F & 13 & 51 & 111 & 23 & 12 & 16 \\
H71L & 0 & 34 & 68 & 48 & 23 & 16 \\
L352P & 0 & 8 & 3 & 10 & 6 & 4 \\
L565P & 12 & 14 & 5 & 0 & 8 & 0 \\
R916C & 8 & 26 & 63 & 45 & 33 & 11 \\
\hline
\end{tabular}

\section{Conclusions}

The development of molecules that restore partial mutant enzyme folding, trafficking, and activity is highly desirable in the context of protein folding diseases, which includes many of the clinical forms of the lysosomal storage disorders. Whereas a variety of active site-directed competitive inhibitors with a glycomimetic structure have shown promise for PC therapy targeting several of such conditions, with a representative already in the market, to the best of our knowledge no reports showing the potential of this therapeutic strategy for the treatment of AM are available. The location of the active site at the surface of the dysfunctional protein in AM, LAMAN, represents a major hurdle for PC efficiency in this case. In the light of the recent discoveries regarding aglycone and multivalent effects in enzyme inhibition, we conceived that mono or multivalent glycoside mimics with the capability to interact simultaneously at the catalytic receptacle and at allosteric sites could accomplish the task. By 
using the OMJ $\mathrm{N}$-glycoside motif as glycone binding motif, a collection of conjugates differing in the aglycone nature as well as homo and hetero-multiconjugates built on a $\beta$-cyclodextrin scaffold were prepared and evaluated for their inhibitor/effector character towards wild type and AM-associated mutant LAMAN. The sensitiveness of LAMAN to multivalent enzyme inhibition was evidenced in human fibroblast lysates. Regarding the chaperoning properties, multivalent derivatives (7-9) showed some benefit for mutations remote to the catalytic site, e.g. R750W, but the inhibitory character prevailed in most cases. On the contrary, monovalent OMJ derivatives equipped with aglycone moieties susceptible of engaging in productive interactions with aglycone sites in the enzyme significantly enhanced mutant LAMAN activity in AM patient fibroblasts and in MAN2B1-KO HAP1 cells expressing several AM causative LAMAN mutations. The responsiveness to PC treatment was strongly dependent on both LAMAN mutation and PC structure. Thus, the OMJ- $\beta C D$ conjugate 6 exhibited high efficiency in folding-defective mutants at very low $(2 \mathrm{nM})$ concentrations, but higher concentrations led to inhibitor/chaperone compensation effects, which was not the case for OMJ chaperones bearing aliphatic aglycons such as $\mathbf{4}$. Interestingly, the later compound was also able to greatly enhance the activity of the active site $\mathrm{H} 72 \mathrm{~L} / \mathrm{H} 72 \mathrm{~L}$ mutant LAMAN by increasing its overall stability. Activity enhancement was accompanied by an increase in the protein charge in the lysosome and a reduction of cholesterol content in the cell, reflecting a substantial improvement in endosomal/lysosomal function.

The significance of the ensemble of results discussed herein in the medicinal chemistry context is twofold. First, they highlight that multivalent enzyme inhibition is not a phenomenon restricted to isolated model plant glycosidases, but that it also operates in a biological context. Yet, much work is necessary to realize the potential of multivalent enzyme inhibition as a tool in biomedicine: although some preliminary results claimed a certain potential in PC therapies, ${ }^{66-68}$ the possibility of cross-interactions with other enzymes and unfavorable enzyme-inhibitor dissociation kinetics needs to be seriously taken into account. Second, our 
work provides solid proof on the suitability of the OMJ $\mathrm{N}$-glycoside prototype for the development of PC candidates targeting AM disease based on the glycone/aglycone multipoint interaction concept. PCs can be further combined with regulators of the homeostasis enhancing the capacity of the endoplasmic reticulum to fold misfolding-prone proteins ${ }^{69}$ as well as with hrLAMAN used in ERT in search for an efficient treatment of AM. Work in that direction is currently sought in our laboratories.

\section{Experimental}

General Methods. All chemicals were reagent grade and used as supplied unless otherwise specified. Dulbecco's Modified Eagle's Medium (DMEM) and Protein Assay Rapid kit were obtained from Wako (Tokyo, Japan). Isocove's Modified Dulbecco's Medium (IMDM) and Amplex red cholesterol assay kit were obtained from Thermo Fisher Scientific (Tokyo, Japan). The human MAN2B1 knockout (KO) HAP1 cell line was obtained from Horizon Discovery (Cambridge, UK). Fetal bovine serum (FBS) was from HyClone Lab. (Waltham, MS). 4methylumbelliferone (4-MU)-conjugated- $\alpha$-D-mannopyranoside was from Sigma (St. Louis, MO). Human mutant MAN2B1 cDNA expression vectors were obtained from GenScript Japan (Tokyo, Japan). Lipofectamine 2000 transfection reagent was from Invitrogen Corp. (Carlsbad, CA). Rabbit polyclonal anti-MAN2B1 was purchased from Abcam Japan (Tokyo, Japan). Rabbit polyclonal anti- $\beta$-tubulin was from Santa Cruz Biotechnology Inc. (Santa Cruz, CA). Horseradishperoxidase-conjugated secondary antibody and ECL plus detection kit were from GE Healthcare Bioscience (Buckinghamshire, UK). OptiPrep density gradient medium was from Axis-Shield (Oslo, Norway).Optical rotations were measured at $20 \pm 2{ }^{\circ} \mathrm{C}$ in 1-dm tubes on a Jasco P-2000 polarimeter. ${ }^{1} \mathrm{H}$ (and ${ }^{13} \mathrm{C}$ NMR) spectra were recorded at 500 (125.7) MHz with Bruker 500 DRX magnet. 1D TOCSY, 2D COSY, HMQC and HSQC experiments were used to assist on NMR assignments. Thin-layer chromatography (TLC) was carried out on aluminum sheets coated with silica gel 60 F254 Merck with visualization by UV light and by charring with ethanolic $10 \% \mathrm{H}_{2} \mathrm{SO}_{4}$ and $0.1 \%$ ninhydrin. Column chromatography was carried out on Silica 
Gel 60. ESI mass spectra were recorded on a Bruker Daltonics Esquire6000 ${ }^{\mathrm{TM}}$ ion-trap mass spectrometer. All compounds were purified to $\geq 95 \%$ purity as determined by elemental microanalysis results obtained on a CHNSTruSpect Micro elemental analyzer (Instituto de Investigaciones Químicas, Spain) from vacuum-dried samples. The analytical results for $\mathrm{C}, \mathrm{H}, \mathrm{N}$, and $\mathrm{S}$ were within \pm 0.4 of the theoretical values. 1-Amino- $N$-octyl-5,6-oxomethylidene-1deoxymannojirimycin (1), ${ }^{70} \mathrm{~N}$-(6-azidoaminohexyl)-5,6-oxomethylidene-1deoxymannojirimycin (2), ${ }^{52} \mathrm{~N}$-(9-azidoaminononyl)-5,6-oxomethylidene-1deoxymannojirimycin (3), ${ }^{52} \mathrm{~N}$-(9-N-tert-butoxycarbonylaminonyl)-5,6-oxomethylidene-1deoxymannonojirimycin (4), ${ }^{52}$ 1-amino-1-deoxy- $N$-(6-(4-propyl-1H-1,2,3-triazol-1-yl)hexyl)-5,6oxomethylidenemannojirimycin (5), ${ }^{52} 6^{\prime \prime}$-V"-hexa-O-methyl-6'-O-propargyl-heptakis(2,3-di-Omethyl)cyclomaltoheptaose (11), ${ }^{71}$ hepta(2,3-di-O-methyl-6-O-propargyl)cyclomaltoheptaose (12) ${ }^{72}$ heptakis(2,6-di-O-propargyl)cyclomaltoheptaose (13), ${ }^{72} 6$-azidohexyl $\alpha$-Dmannopyranoside (14), ${ }^{73}$ were prepared following reported procedures. Compounds 1-5 were examined for known classes of assay interference compounds using the freely available research tool for ligand discovery ZINC 15 (http://zinc15. docking.org). ${ }^{74}$

\section{6'-O-(1-(1-Amino-5,6-oxomethylidene-1-deoxymannojirimycinyl)hexyl-1H-1,2,3-triazol-4-} yl)methyl-6"-VII-hexa-O-methyl-heptakis(2,3-di-O-methyl)cyclomaltoheptaose (6). To a solution of $\mathbf{1 1}(50 \mathrm{mg}, 34 \mu \mathrm{mol})$ and the corresponding 6-azidohexyl derivative $(\mathbf{2}, 0.05 \mathrm{mmol})$ in 3:1 acetone-MeOH (10 mL), Cul.(EtO) $)_{3} \mathrm{P}(1.2 \mathrm{mg}, 3.4 \mu \mathrm{mol})$ and DIPEA (6 $\left.\mu \mathrm{L}, 34 \mu \mathrm{mol}\right)$ were added and the reaction mixture was refluxed for $24 \mathrm{~h}$. The solvent was evaporated under vacuum and the residue was purified by column chromatography $\left(30: 1 \rightarrow 10: 1 \mathrm{CH}_{2} \mathrm{Cl}_{2}-\mathrm{CH}_{3} \mathrm{OH}\right)$. Yield: $60 \mathrm{mg}$ (99\%). $\mathrm{R}_{f} 0.35$ (10:1 $\left.\mathrm{CH}_{2} \mathrm{Cl}_{2}-\mathrm{CH}_{3} \mathrm{OH}\right) .[\alpha]_{\mathrm{D}}+129.8$ (c 1.0, $\left.\mathrm{CH}_{3} \mathrm{OH}\right) .{ }^{1} \mathrm{H} \mathrm{NMR}(500 \mathrm{MHz}$, $\left.\mathrm{CD}_{3} \mathrm{OD}\right) \delta 7.97(\mathrm{~s}, 1 \mathrm{H},=\mathrm{CH}), 5.15\left(\mathrm{~m}, 6 \mathrm{H}, \mathrm{H}-1^{\mathrm{II}-\mathrm{VII}}\right), 5.05\left(\mathrm{~d}, 1 \mathrm{H}, \mathrm{J}_{1,2}=3.3 \mathrm{~Hz}, \mathrm{H}-1^{\prime}\right), 4.70-4.59(\mathrm{~m}$, $\left.2 \mathrm{H}, \mathrm{CH}_{2} \mathrm{O}\right), 4.58\left(\mathrm{bs}, 1 \mathrm{H}, \mathrm{H}-1_{\mathrm{MN}}\right), 4.49\left(\mathrm{t}, 1 \mathrm{H}, J_{5,6}=J_{6 \mathrm{a}, 6 \mathrm{~b}}=8.6 \mathrm{~Hz}, \mathrm{H}-6 \mathrm{a}_{\mathrm{MN}}\right), 4.40\left(\mathrm{t}, 2 \mathrm{H}, \mathrm{J}_{\mathrm{H}, \mathrm{H}}=7 \mathrm{~Hz}\right.$, $\left.\mathrm{H}-1_{\text {Hex }}\right), 4.29$ (dd, $\left.1 \mathrm{H}, J_{5,6 \mathrm{~b}}=4.4 \mathrm{~Hz}, \mathrm{H}-6 \mathrm{~b}_{\mathrm{MN}}\right), 4.09-4.07$ (m, $\left.1 \mathrm{H}, \mathrm{H} .6 \mathrm{a}^{\prime}\right), 3.95$ (bs, $\left.1 \mathrm{H}, \mathrm{H}-1_{\mathrm{MN}}\right), 3.88-$ $3.79(\mathrm{~m}, 14 \mathrm{H}, \mathrm{H}-6), 3.73-3.57\left(\mathrm{~m}, 30 \mathrm{H}, \mathrm{H}-5_{\mathrm{MN}}, \mathrm{H}-3_{\mathrm{MN}}, \mathrm{H}-4_{\mathrm{MN}}, \mathrm{OMe}, \mathrm{H}-5\right), 3.56-3.48(\mathrm{~m}, 29 \mathrm{H}$, 
OMe, H-3), 3.36 (m, $15 \mathrm{H}, \mathrm{OMe}), 3.16-3.13\left(\mathrm{~m}, 6 \mathrm{H}, \mathrm{H}-2^{2-\mathrm{VII}}\right), 3.10\left(\mathrm{~d}, 1 \mathrm{H}, \mathrm{H}-2^{\prime}\right), 2.58$ (bs, $2 \mathrm{H}, \mathrm{H}-$ $\left.6_{\text {Hех }}\right), 1.92\left(m, 2 \mathrm{H}, \mathrm{H}-2_{\text {Hех }}\right), 1.53\left(\mathrm{~m}, 2 \mathrm{H}, \mathrm{H}-5_{\text {Hех }}\right), 1.37$ ( $\left.m, 4 \mathrm{H}, \mathrm{H}-4_{\text {Hех }}, \mathrm{H}-3_{\text {Hех }}\right) .{ }^{13} \mathrm{C}$ NMR $(125.7$ $\mathrm{MHz}, \mathrm{CD}_{3} \mathrm{OD}$ ) $\delta 160.2$ (CO), 149.8 (C-4 triazole), 125.1 (C-5 triazole $), 99.7,99.5$ (C-1"1-VIII), 99.3 (C-1'), 83.5, 83.2, 83.1, 82.9 (C-2, C-3), 81.1, 81.0, 80.9, 80.7, 80.5 (C-4), 73.0 (C-2MN) $, 72.8,72.5$ (C-5), 72.4 (C-3 $\left.3_{\mathrm{MN}}\right), 72.3,72.2$ (C-6), 72.0 (C-4 $\left.4_{\mathrm{MN}}, \mathrm{C}-1_{\mathrm{MN}}\right), 70.3\left(\mathrm{C}-6^{\prime}\right), 67.9\left(\mathrm{C}-6_{\mathrm{MN}}\right), 65.1\left(\mathrm{CH}_{2} \mathrm{O}\right), 62.0,61.9$, 61.8 (OMe), 59.4, 59.2, 59.1, 59.0, 59.0, 58.8 (OMe), 55.6 (C-5 $\left.5_{\text {MNs }}\right), 51.2\left(\mathrm{C}-1_{\mathrm{Hex}}\right), 46.8$ (C-6 $\left.6_{\text {Hех }}\right)$,

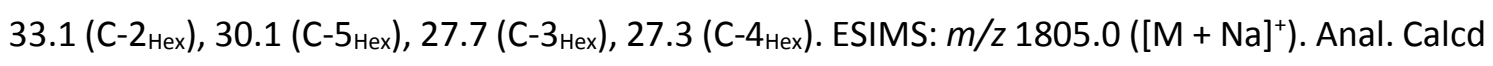
for $\mathrm{C}_{78} \mathrm{H}_{135} \mathrm{~N}_{5} \mathrm{O}_{40}: \mathrm{C}, 52.55 ; \mathrm{H}, 7.63 ; \mathrm{N}, 3.93$. Found: $\mathrm{C}, 52.18 ; \mathrm{H}, 7.32 ; \mathrm{N}, 4.09$.

\section{Heptakis[2,3-di-O-methyl-6-O-(1-amino-5,6-oxomethylidene-1-}

deoxymannojirimycinyl)hexyl-1H-1,2,3-triazol-4-ylmethyl]cyclomaltoheptaose (7). To a solution of $\mathbf{1 2}$ (30 mg, $18.9 \mu \mathrm{mol})$ and the corresponding 6-azidohexyl derivative $(2,0.16 \mathrm{mmol})$ in acetone-MeOH (2:1, $20 \mathrm{~mL})$, Cul.(EtO) ${ }_{3} \mathrm{P}(5 \mathrm{mg}, 13.0 \mu \mathrm{mol})$ and DIPEA ( $\left.22 \mu \mathrm{L}, 0.13 \mathrm{mmol}\right)$ were added and the mixture was refluxed overnight for $24 \mathrm{~h}$. The solvents were evaporated and the resulting residue was purified by column chromatography Column chromatography (6:3:1 MeCN- $\mathrm{H}_{2} \mathrm{O}-\mathrm{NH}_{4} \mathrm{OH}$ ). Yield: $62.4 \mathrm{mg}(84 \%) . R_{f} 0.25$ (6:3:1 MeCN- $\mathrm{H}_{2} \mathrm{O}-\mathrm{NH}_{4} \mathrm{OH}$ ). $[\alpha]_{\mathrm{D}}+66.0$ (c 1.0, $\mathrm{H}_{2} \mathrm{O}$ ). ${ }^{1} \mathrm{H} N M R\left(500 \mathrm{MHz}, \mathrm{CD}_{3} \mathrm{OD}, 323 \mathrm{~K}\right) \delta 7.98(\mathrm{~s}, 7 \mathrm{H},=\mathrm{CH}), 5.10$ (bs, $\left.7 \mathrm{H}, \mathrm{H}-1\right), 4.65-4.55(\mathrm{~m}, 14$ $\left.\mathrm{H}, \mathrm{OCH}_{2}\right), 4.61\left(\mathrm{~s}, 7 \mathrm{H}, \mathrm{H}-1_{\mathrm{MN}}\right), 4.50\left(\mathrm{t}, 7 \mathrm{H}, \mathrm{J}_{6 \mathrm{a}, 6 \mathrm{~b}}=8.7 \mathrm{~Hz}, \mathrm{H}-6 \mathrm{a}_{\mathrm{MN}}\right), 4.38\left(\mathrm{bs}, 14 \mathrm{H}, \mathrm{H}-1_{\mathrm{Hex}}\right), 4.30$ $\left(d d, 7 \mathrm{H}, J_{5,6 b}=4.4 \mathrm{~Hz}, \mathrm{H}-6 \mathrm{~b}_{M N \mathrm{M}}\right), 3.98\left(\mathrm{~s}, 7 \mathrm{H}, \mathrm{H}-2_{\mathrm{MN}}\right), 3.84\left(\mathrm{dd}, 7 \mathrm{H}, J_{6 \mathrm{a}, 6 \mathrm{~b}}=11.8 \mathrm{~Hz}, J_{5,6 \mathrm{a}}=2.6 \mathrm{~Hz}\right.$, H-6amNs), 3.81 (m, 7 H, H-2MNs), 3.85 (bs, $7 \mathrm{H}, \mathrm{H}-5), 3.77-3.68$ (m, $35 \mathrm{H}, \mathrm{H}-3_{M N}, \mathrm{H}-4_{M N J}, \mathrm{H}-5_{M N J}, \mathrm{H}-$ 6), $3.65(\mathrm{~s}, 21 \mathrm{H}, \mathrm{OMe}), 3.65(\mathrm{~m}, 7 \mathrm{H}, \mathrm{H}-4), 3.54-3.52(\mathrm{~m}, 7 \mathrm{H}, \mathrm{H}-3), 3.51$ (s, $21 \mathrm{H}, \mathrm{OMe}), 3.13$ (bs, $7 \mathrm{H}, \mathrm{H}-2), 2.61-2.56\left(\mathrm{~m}, 14 \mathrm{H}, \mathrm{H}-6_{\text {Hех }}\right), 1.93-1.87$ (m, $\left.14 \mathrm{H}, \mathrm{H}-2_{\text {Hех }}\right), 1.52-1.49$ (m, $14 \mathrm{H}, \mathrm{H}-5_{\text {Hех }}$ ), 1.40-1.30 (m, $\left.28 \mathrm{H}, \mathrm{H}-3_{\text {Hex }}, \mathrm{H}-4_{\text {Hex }}\right) .{ }^{13} \mathrm{C}$ NMR (125.7 MHz, CDCl, $\left.323 \mathrm{~K}\right) \delta 160.1$ (CO), 146.0 (C-4 triazole), 125.2 (C-5 triazole), 99.6 (C-1), 83.5 (C-3), 83.2 (C-2), 80.6 (C-4), 73.2 (C-2 $\mathrm{MN}), 72.7,72.2$ (C-3 $\left.3_{\mathrm{MN}}, \mathrm{C}-4_{\mathrm{MN}}\right), 72.5(\mathrm{C}-5), 72.0\left(\mathrm{C}-1_{\mathrm{MN}}\right), 70.7(\mathrm{C}-6), 68.0\left(\mathrm{C}-6_{\mathrm{MNN}}\right), 65.4\left(\mathrm{OCH}_{2}\right), 61.759 .0(\mathrm{OMe})$,

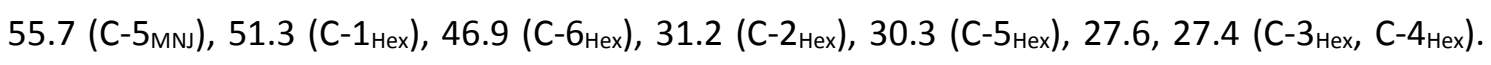


ESIMS: $m / z 1323.8\left([\mathrm{M}+3 \mathrm{Na}]^{3+}\right), 1974.1\left([\mathrm{M}+2 \mathrm{Na}]^{2+}\right)$. Anal. Calcd for $\mathrm{C}_{168} \mathrm{H}_{273} \mathrm{~N}_{35} \mathrm{O}_{70}: \mathrm{C}, 51.70$; $H, 7.05 ; \mathrm{N}, 12.56$. Found: C, 51.56; H, 6.98; N, 12.45 .

Heteroheptavalent Mannose-1-deoxymannojirimycin CD Derivative (8). A solution of 12

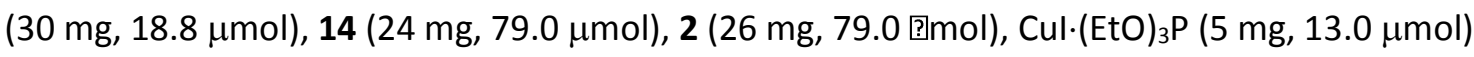
and DIPEA ( $22 \mu \mathrm{L}, 0.13 \mathrm{mmol})$ in a mixture acetone-MeOH $(2: 1,15 \mathrm{~mL})$ was refluxed overnight. The solvents were evaporated and the crude purified by column chromatography (12:6:1 $\left.\rightarrow 6: 3: 1 \mathrm{MeCN}-\mathrm{H}_{2} \mathrm{O}-\mathrm{NH}_{4} \mathrm{OH}\right)$. Yield: $68.3 \mathrm{mg}(96 \%) . R_{\mathrm{f}} 0.50\left(6: 3: 1 \mathrm{CH}_{3} \mathrm{CN}-\mathrm{H}_{2} \mathrm{O}-\mathrm{NH}_{4} \mathrm{OH}\right) .{ }^{1} \mathrm{H}$ NMR (500 MHz, CD ${ }_{3} \mathrm{OD}, 323 \mathrm{~K}$ ) 回 7.97 (s, =CH), 5.09 (bs, $\left.7 \mathrm{H}, \mathrm{H}-1\right), 4.75$ (s, $\left.4 \mathrm{H}, \mathrm{H}-1_{\mathrm{Man}}\right)$, 4.65$4.55\left(\mathrm{~m}, \mathrm{OCH}_{2}\right), 4.60\left(\mathrm{~s}, 3 \mathrm{H}, \mathrm{H}-1_{\mathrm{MN}}\right), 4.50\left(\mathrm{t}, \mathrm{J}_{6 \mathrm{a}, 6 \mathrm{~b}}=8.7 \mathrm{~Hz}, \mathrm{H}-6 \mathrm{a}_{\mathrm{MN}}\right), 4.38\left(\mathrm{~m}, \mathrm{H}-1_{\text {Hex }}\right), 4.30$ (dd, $\left.\mathrm{J}_{5,6 \mathrm{~b}}=4.6 \mathrm{~Hz}, \mathrm{H}-6 \mathrm{~b}_{\mathrm{MN}}\right), 3.98$ (bs, $\mathrm{H}-2^{\prime \prime}$ ), 3.83 (dd, $\mathrm{J}_{6 \mathrm{a}, 6 \mathrm{~b}}=11.7 \mathrm{~Hz}, \mathrm{~J}_{5,6 \mathrm{a}}=2.5 \mathrm{~Hz}, \mathrm{H}-6 \mathrm{a}_{\mathrm{Man}}$ ), 3.80 (m,

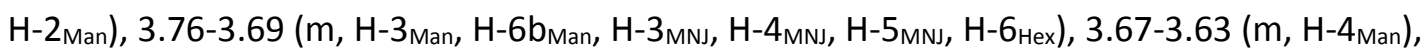
3.65 (s, OMe), 3.56-3.51 (m, H-3, H-5 Man), 3.51 (s, OMe), 3.45-3.41 (m, H-6 Hex ), 3.13 (bs, H-2),

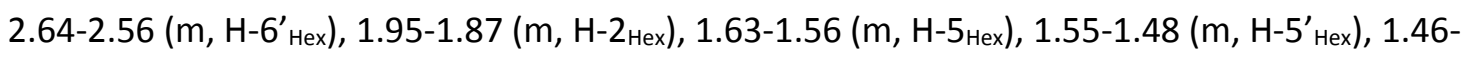
$1.40\left(\mathrm{~m}, \mathrm{H}-4_{\text {Hех }}\right), 1.39-1.30$ (m, H-3 $\left.{ }_{\text {Hех }}, \mathrm{H}-4^{\prime}{ }_{\text {Hех }}\right) .{ }^{13} \mathrm{C} \mathrm{NMR}\left(125.7 \mathrm{MHz}, \mathrm{CD}_{3} \mathrm{OD}, 313 \mathrm{~K}\right) \delta 160.1$ (CO), 146.1 (C-4 triazole), 125.2 (C-5 triazole), 101.6 (C-1 Man ), 99.7 (C-1), 83.5 (C-3), 83.2 (C-2), 80.6 (C-4), 74.6 (C-5 $\left.5_{\mathrm{Man}}\right), 73.2$ (C-2 $\left.{ }_{\mathrm{MN}}\right), 72.8$ (C-3 $\left.3_{\mathrm{Man}}\right), 72.6$ (C-3 $3_{\mathrm{MN}}$ or C- $\left.4_{\mathrm{MN}}\right), 72.5$ (C-5), 72.3 (C$\left.2_{\mathrm{Man}}\right), 72.2$ (C-3 $3_{\mathrm{MN}}$ or $\left.\mathrm{C}-4_{\mathrm{MN}}\right), 72.0$ (C-1 $\left.1_{\mathrm{MN}}\right), 70.7$ (C-6), 68.9 (C-4 $\left.4_{\mathrm{Man}}\right), 68.5$ (C-6 $\left.6_{\mathrm{Hex}}\right), 68.0$ (C-6 $\left.6_{\mathrm{MN}}\right)$, $65.4\left(\mathrm{OCH}_{2}\right.$-triazole), 63.1 (C-6 $\left.{ }_{\mathrm{Man}}\right), 61.8,59.0(\mathrm{OMe}), 55.7$ (C-5 $\left.{ }_{\mathrm{MN}}\right), 51.3\left(\mathrm{C}-1_{\mathrm{Hex}}\right), 46.9\left(\mathrm{C}-6^{\prime}{ }_{\text {Hex }}\right)$,

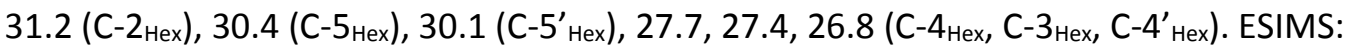
Attached mannose residues number is indicated within brackets: $m / z 1291.8\left([\mathrm{M}(4)+3 \mathrm{Na}]^{3+}\right)$, $1926.2\left([\mathrm{M}(4)+2 \mathrm{Na}]^{2+}\right)$.

Heterotetradecavalent Mannose-1-deoxymannojirimycin CD Derivative (9). A solution of 13 (15 mg, $9.0 \mu \mathrm{mol}), 14$ (23 mg, $76.0 \mu \mathrm{mol}), 2$ (25 mg, $76.0 \mu \mathrm{mol})$, Cul.(EtO) ${ }_{3} \mathrm{P}(5 \mathrm{mg}, 13.0$ $\mu \mathrm{mol})$ and DIPEA $(21 \mu \mathrm{L}, 0.13 \mathrm{mmol})$ in a mixture acetone-MeOH $(1: 1,10 \mathrm{~mL})$ was refluxed overnight. The solvents were evaporated and the crude purified by column chromatography 
(2:1:1 $\left.\rightarrow 3: 2: 2 \mathrm{MeCN}-\mathrm{H}_{2} \mathrm{O}-\mathrm{NH}_{4} \mathrm{OH}\right)$. Yield: $53.0 \mathrm{mg}(96 \%) . R_{\mathrm{f}} 0.23\left(2: 1: 1 \mathrm{CH}_{3} \mathrm{CN}: \mathrm{H}_{2} \mathrm{O}: \mathrm{NH}_{4} \mathrm{OH}\right) .{ }^{1} \mathrm{H}$ NMR (500 MHz, D $20,343 \mathrm{~K}) \delta 8.49(\mathrm{~s}, 7 \mathrm{H},=\mathrm{CH}), 8.31(\mathrm{~s}, 7 \mathrm{H},=\mathrm{CH}), 5.76\left(\mathrm{~d}, \mathrm{~J}_{1,2}=2.4 \mathrm{~Hz}, \mathrm{H}-1_{\mathrm{MN}}\right)$, $5.39\left(\mathrm{~d},{ }^{2} \mathrm{~J}_{\mathrm{H}, \mathrm{H}}=12.5 \mathrm{~Hz}, \mathrm{OCH}\right)_{2}, 5.38(\mathrm{bs}, \mathrm{H}-1), 5.27\left(\mathrm{~d}, \mathrm{OCH}{ }_{2}\right), 5.26\left(\mathrm{bs}, \mathrm{H}-1_{\mathrm{Man}}\right), 5.11\left(\mathrm{t}, \mathrm{J}_{6 \mathrm{a}, 6 \mathrm{~b}}=\right.$ $\left.\mathrm{J}_{5,6 \mathrm{a}}=8.7 \mathrm{~Hz}, \mathrm{H}-6 \mathrm{a}_{\mathrm{MNu}}\right)$, 5.05-4.99 (m, OCH$\left.)_{2}\right), 4.87\left(\mathrm{~m}, \mathrm{H} 1_{\text {Hex }}, \mathrm{H}-1^{\prime}{ }_{\text {Hex }}\right), 4.82\left(\mathrm{dd}, \mathrm{J}_{5,6 \mathrm{~b}}=6.5 \mathrm{~Hz}, \mathrm{H}-\right.$ $\left.6 b_{M N J}\right), 4.77-4.74\left(m, \mathrm{OCH}_{2}\right), 4.56\left(\mathrm{t}, \mathrm{J}_{2,3}=2.7 \mathrm{~Hz}\right), 4.44-4.39\left(\mathrm{~m}, \mathrm{H}-5_{\mathrm{MN}}\right), 4.37\left(\mathrm{~d}, \mathrm{~J}_{1,2}=1.3 \mathrm{~Hz}, \mathrm{H}-\right.$ $\left.2_{M a n}\right), 4.32\left(d d, J_{3,4}=9.7 \mathrm{~Hz}, \mathrm{H}-3_{M N J}\right), 4.31-4.22\left(m, \mathrm{H}-6_{\mathrm{Man}}, \mathrm{H}-3_{\mathrm{Man}}\right), 4.18-4.06\left(\mathrm{~m}, \mathrm{H}-4_{\mathrm{Man}}\right), 4.06-$

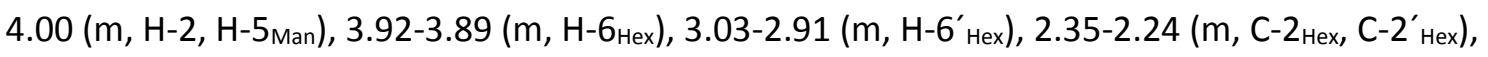
1.98-1.89 (m, H-5 $\left.{ }_{\text {Hex }},{\mathrm{H}-5^{\prime}}_{\text {Hex }}\right), 1.79-1.69\left(\mathrm{~m}, \mathrm{C}-3_{\text {Hex }}, \mathrm{C}-3^{\prime}{ }_{\text {Hex, }} \mathrm{C}-4_{\text {Hex }}, \mathrm{C}-4^{\prime}{ }_{\text {Hex }}\right){ }^{13} \mathrm{C}$ NMR $(100.6 \mathrm{MHz}$, $\mathrm{D}_{2} \mathrm{O}, 333 \mathrm{~K}$ ) $\delta$ 159.7, 158.9 (CO), 144.6, 144.1 (C-5 triazole), 125.5, 124.8 (C-4 triazol), 100.8 (C-

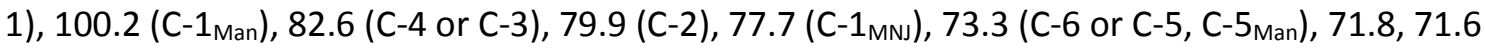
(C-2 $\left.{ }_{\mathrm{MN}}\right), 71.3$ (C-3 $\left.3_{\mathrm{Man}}\right), 71.0,70.7,70.6$ (C-4 $\left.{ }_{\mathrm{MN}}, \mathrm{C}-3_{\mathrm{MN}}\right), 70.7$ (C-2 $\left.{ }_{\mathrm{Man}}\right), 69.2$ (C-5 or C-6), 68.0 (C$\left.6_{\mathrm{Hex}}\right), 67.4$ (C-6 $\left.6_{\mathrm{Hex}}, \mathrm{C}-4_{\mathrm{Man}}\right), 65.0,64.1\left(\mathrm{OCH}_{2}\right.$-triazole), 61.5 (C-6 $\left.6_{\mathrm{Man}}\right), 54.5$ (C-5 $\left.5_{\mathrm{MN}}\right), 50.7,50.5$ (C-

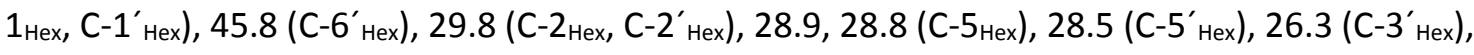
25.9 (C-3 Hex $), 25.3$ (C-4 $\left.{ }_{\text {Hex }}, C^{\prime}-4^{\prime}{ }_{\text {Hex }}\right)$. ESIMS Attached mannose residues number is indicated within brackets: $m / z 2043.1\left([\mathrm{M}(7)+3 \mathrm{Na}]^{3+}\right)$.

\section{Heptakis[2,6-di-O-(1-(1-amino-5,6-oxomethylidene-1-deoxy-mannojirimycinyl)hexyl-1H-} 1,2,3-triazol-4-yl)methyl]cyclomaltoheptaose (10). To a solution of 13 (15 mg, $88.9 \mu \mathrm{mol})$ and the 6-azidohexyl derivative $(2,107 \mu \mathrm{mol})$ in acetone- $\mathrm{MeOH}(1: 1,10 \mathrm{~mL})$, Cul.(EtO) ${ }_{3} \mathrm{P}(13.0 \mu \mathrm{mol})$ and DIPEA (0.11 mmol) were added and the mixture was refluxed overnight. Column chromatography $\quad\left(2: 1: 1 \quad \mathrm{MeCN}-\mathrm{H}_{2} \mathrm{O}-\mathrm{NH}_{4} \mathrm{OH}\right) . \quad$ Yield: $54.5 \quad \mathrm{mg} \quad(95 \%) . \quad R_{f} \quad 0.27 \quad(2: 1: 1$ $\left.\mathrm{CH}_{3} \mathrm{CN}: \mathrm{H}_{2} \mathrm{O}: \mathrm{NH}_{4} \mathrm{OH}\right) .[\alpha]_{\mathrm{D}}+27.4\left(c 1.0, \mathrm{H}_{2} \mathrm{O}\right) .{ }^{1} \mathrm{H} \mathrm{NMR}\left(500 \mathrm{MHz}, \mathrm{D}_{2} \mathrm{O}, 343 \mathrm{~K}\right) \delta 8.47(\mathrm{~s}, 7 \mathrm{H},=\mathrm{CH})$, $8.30(\mathrm{~s}, 7 \mathrm{H},=\mathrm{CH}), 5.76\left(\mathrm{~d}, \mathrm{~J}_{1,2}=2.4 \mathrm{~Hz}, \mathrm{H}-1_{\mathrm{MN}}\right), 5.38\left(\mathrm{~d},{ }^{2} \mathrm{~J}_{\mathrm{H}, \mathrm{H}}=10.8 \mathrm{~Hz}, \mathrm{OCH}_{2}\right), 5.37(\mathrm{bs}, \mathrm{H}-1), 5.27$ $\left(\mathrm{d}, \mathrm{OCH}_{2}\right), 5.10\left(\mathrm{t}, \mathrm{J}_{6 \mathrm{a}, 6 \mathrm{~b}}=J_{5,6 \mathrm{a}}=8.5 \mathrm{~Hz}, \mathrm{H}-6 \mathrm{a}_{\mathrm{MNJ}}\right)$, 5.04-4.96 $\left(\mathrm{m}, \mathrm{OCH}_{2}\right), 4.88-4.84\left(\mathrm{~m}, \mathrm{H}-1_{\mathrm{Hex}}\right), 4.81$ $\left(d d, J_{5,6 b}=6.3 \mathrm{~Hz}, \mathrm{H}-6 \mathrm{~b}_{\mathrm{MN}}\right), 4.74\left(\mathrm{~m}, \mathrm{H}-1_{\mathrm{Hex}}\right), 4.55\left(\mathrm{t}, J_{2,3}=2.6 \mathrm{~Hz}, \mathrm{H}-2_{\mathrm{MN}}\right), 4.41\left(\mathrm{~m}, \mathrm{H}-5_{\mathrm{MN}}\right), 4.31$ (dd, $\left.J_{3,4}=9.7 \mathrm{~Hz}, \mathrm{H}-3_{\mathrm{MN}}\right)$, 4.28-419 (m, H-3, H-6, H-5, H-4 $\left.{ }_{M N \mathrm{~s}}\right), 4.00(\mathrm{~m}, \mathrm{H}-2), 3.89$ (m, H-4),3.04-

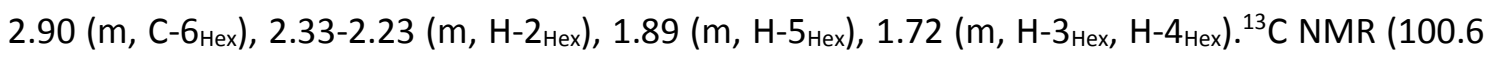


MHz, $\left.\mathrm{D}_{2} \mathrm{O}, 333 \mathrm{~K}\right)$ $\delta 159.7,158.9$ (CO), 144.6, 144.1 (C-5 triazole), 125.5, 124.8 (C-4 triazol), 100.7

(C-1), 82.4 (C-4), 79.9 (C-2), 77.7 (C-1 $\left.1_{\mathrm{MN}}\right), 73.3$ (C-6), 71.8, 71.6 (C-2 $\left.2_{\mathrm{MN}}\right), 71.0,70.7,70.6$ (C-4 $4_{\mathrm{MN}}$, C-3 $\left.3_{\mathrm{MN}}\right), 69.2(\mathrm{C}-5), 68.0$ (C-6 $\left.{ }_{\mathrm{MN}}\right), 65.0,64.1\left(\mathrm{OCH}_{2}\right.$-triazole), 54.4 (C-5 $\left.5_{\mathrm{MN}}\right), 50.7,50.5\left(\mathrm{C}-1_{\mathrm{Hex}}\right), 45.8$

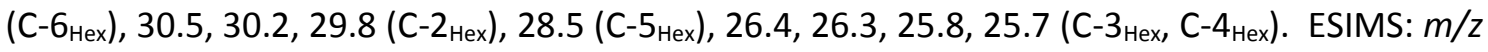
$1592.5\left([\mathrm{M}+4 \mathrm{Na}]^{4+}\right), 2115.4\left([\mathrm{M}+3 \mathrm{Na}]^{3+}\right)$.

Inhibition Studies with Commercial Enzymes. Inhibition constant $\left(K_{\mathrm{i}}\right)$ values were determined by spectrophotometrically measuring the residual hydrolytic activities of the glycosidases against the respective $p$-nitrophenyl $\alpha$ - or $\beta$-D-glycopyranoside or $o$-nitrophenyl $\beta$-Dgalactopyranoside (for $\beta$-galactosidases) in the presence of the $\mathrm{OMJ}$ chaperone candidate. Each essay was performed in phosphate buffer or phosphate-citrate buffer (for $\alpha$ - or $\beta$ - mannosidase and amyloglucosidase) at the optimal $\mathrm{pH}$ of each enzyme. The reactions were initiated by addition of enzyme to a solution of the substrate in the absence or presence of various concentrations of inhibitor. The mixture was incubated for $10-30$ min at $37{ }^{\circ} \mathrm{C}$ or $55{ }^{\circ} \mathrm{C}$ (for amyloglucosidase) and the reaction was quenched by addition of $1 \mathrm{M} \mathrm{Na}_{2} \mathrm{CO}_{3}$. Reaction times were appropriate to obtain $10-20 \%$ conversion of the substrate in order to achieve linear rates. The absorbance of the resulting mixture was determined at $405 \mathrm{~nm}$. Approximate values of $K_{\mathrm{i}}$ were determined using a fixed concentration of substrate (around the $K_{\mathrm{m}}$ value for the different glycosidases) and various concentrations of inhibitor. Full $K_{\mathrm{i}}$ determinations and enzyme inhibition mode were determined from the slope of Lineweaver-Burk plots and double reciprocal analysis.

Human LAMAN Enzyme Assay. Human LAMAN enzyme activity in cell lysate was measured by using 4-MU substrate. Briefly, cells in 35-mm dishes were washed with PBS and collected in $200 \mu \mathrm{L} 0.1 \%$ Triton X-100 in distilled $\mathrm{H}_{2} \mathrm{O}$. After centrifugation $\left(6,000 \mathrm{rpm}\right.$ for $15 \mathrm{~min}$ at $\left.4{ }^{\circ} \mathrm{C}\right)$ to remove insoluble materials, $2 \mu \mathrm{L}$ of lysates with $4 \mu \mathrm{L}$ of the substrate solution in $0.1 \mathrm{M}$ citrate buffer ( $\mathrm{pH}$ 4) was incubated at $37^{\circ} \mathrm{C}$ for $60 \mathrm{~min}$ and the reaction was terminated by adding 0.2 $\mathrm{M}$ glycin- $\mathrm{NaOH}$ buffer ( $\mathrm{pH}$ 10.7). The liberated 4-MU was measured with a fluorescence plate 
reader (excitation 340 nm; emission 460 nm; Infinite F500, TECAN Japan, Kawasaki, Japan). Protein concentrations were determined using Protein Assay Rapid Kit (WAKO, Tokyo, Japan) and enzyme activity was normalized by protein concentration.

Inhibition of LAMAN in vitro. Cell lysates in $0.1 \%$ Triton $\mathrm{X}-100$ in distilled $\mathrm{H}_{2} \mathrm{O}$ from normal skin fibroblasts were used. Lysates were mixed with 4-MU substrate in the absence or presence of increasing concentrations of PCs, incubated at $37{ }^{\circ} \mathrm{C}$ for $60 \mathrm{~min}$ and the reaction was terminated by adding $0.2 \mathrm{M}$ glycin- $\mathrm{NaOH}$ buffer $(\mathrm{pH}$ 10.7). The liberated 4-MU was measured with a fluorescence plate reader as described above.

Cell Culture, Transfection and PC Treatment. Human normal skin fibroblasts were maintained in our laboratory. Human skin fibroblasts from AM patients were obtained from Corriel Institute (Camden, NJ). These cells were cultured in DMEM supplemented with $10 \%$ FBS. Human MAN2B1-KO HAP1 cells were cultured in IMDM supplemented with 10\% FBS. For transfection, MAN2B1-KO cells were prepared in 35-mm cultured dishes and transfected with human mutant MAN2B1 expression vectors using Lipofectamine 2000 reagent as described previously. ${ }^{75}$ For PC treatment, cells were cultured in the medium with or without PCs for $96 \mathrm{~h}$ and LAMAN activity in lysates were measured.

Subcellular Fractionation, Lipid Analysis and Western Blotting. Cells were lysed by sonication in $10 \mathrm{mM}$ Tris- $\mathrm{HCl}$ (pH 7.4), $150 \mathrm{mM} \mathrm{NaCl}, 1$ mM EDTA, 1 mM EGTA, 1\% Triton X-100 and a protease inhibitor cocktail (Roche Diagnostics) and the supernatants were used as total extracts. The amount of total cholesterol in total extracts were measured using Amplex red cholesterol assay kit following the manufacture's instruction. For subcellular fractionation, extracted proteins were subjected to continuous gradient ultracentrifugation $(90,000 \mathrm{~g}$ for $20 \mathrm{~h}$ at $4{ }^{\circ} \mathrm{C}$ in SW 41Ti rotor) in OptiPrep gradient (Axis-Shield, Norway) as described previously. ${ }^{32}$ The top 22 fractions of the gradients were recovered and subjected to $\beta$-galactosidase enzyme assay and western blotting. Western blotting was performed as described previously. ${ }^{76}$ Signals 
from horseradish peroxidase-conjugated secondary antibodies were visualized by ECL plus detection reagent and images were obtained using LAS-4000 lumino image analyzer (Fujifilm, Tokyo, Japan).

\section{ASSOCIATED CONTENT}

\section{Supporting Information}

The Supporting Information is available free of charge on the ACS Publications website at DOI: 10.1021/acs.jmedchem

Copies of the ${ }^{1} \mathrm{H}$ and ${ }^{13} \mathrm{C}$ NMR spectra of all new compounds, inhibition constant $\left(K_{\mathrm{i}}\right)$ values for 1-10 against commercial glycosidases, with the corresponding Lineweave-Burk/Dixon plots, experimental procedure to monitor the stability of the heteromultivalent PCs 8 and $\mathbf{9}$ towards GH38 $\alpha$-mannosidase and molecular formula strings; for the 1:1 statistically OMJmannopyranosyl substuted conjugates $\mathbf{8}$ and $\mathbf{9}$, representative structures have been used to generate the molecular formula strings (CSV).

\section{AUTHOR INFORMATION}

\section{Corresponding Authors}

*K.H.: phone, +81 85938 6472; fax, +81 85938 6470; e-mail, kh4060@med.tottori-u.ac.jp.

*J.M.G.F.: phone, +34 954489553; fax, +34 954460161; e-mail, jogarcia@iiq.csic.es.

*C.O.M.: phone, +34 954559806, fax, +34 954624960; e-mail, mellet@us.es

ORCID ID

José M. García Fernández: 0000-0002-6827-0387

Carmen Ortiz Mellet: 0000-0002-7676-7721

\section{Author Contributions}


${ }^{\# R}$ R.R.-C. and R.M. contributed equally. All authors have given approval to the final version of the manuscript.

\section{Notes}

The authors declare no competing financial interest.

\section{ACKNOWLEDGMENTS}

This work was supported by grants from the Spanish Ministry of Economy and Competitiveness: SAF2016-76083-R (MINECO-FEDER) and CTQ2015-64425-C2-1-R (MINECOFEDER), the Junta de Andalucía (contract number FQM2012-1467) and partly supported by the JSPS KAKENHI Grant 17K10051. Technical assistance from the research support services of the University of Seville (CITIUS) is also gratefully acknowledged.

\section{ABBREVIATIONS USED}

AM, $\alpha$-mannosidosis; LAMAM, lysosomal $\alpha$-mannosidase; rhLAMAN, recombinant human LAMAN; PC, pharmacological chaperone; PCT, pharmacological chaperone therapy; ER, endoplasmic reticulum; ERAD, ER-associated degradation; ERT, enzyme replacement therapy; 4-MU, 4-methylumbeliferone; OMJ, $5 N, 60$-oxomethylidenemannonojirimycin; $\beta C D, \beta$ cyclodextrin; HCT, hematopoietic stem cell transplantation; LSDs, lysosomal storage disorders; EMA, European Medicines Agency; CAZy, Carbohydrate-Active enZymes; CuAAc, copper(I)catalyzed azide-alkyne coupling; CNS, central nervous system; HAP1, human near-aploid cell line.

\section{REFERENCES}

1. Borgwardt L.; Lund, A. M.; Dali, C. I. Alpha-mannosidosis - a review of genetic, clinical findings and options of treatment. Pediatr. Endocrinol. Rev. 2014, 12 (Suppl 1), 185-191. 
2. Paciotti, S.; Codini, M.; Tasegian, A.; Ceccarini, M. R.; Cataldi, S.; Arcuri, C.; Fioretti, B.; Albi, E.; Beccari, T. Lysosomal alpha-mannosidase and alpha-mannosidosis. Front. Biosci. 2017, 22, $157-167$.

3. Ceccarini, M. R.; Codini, M.; Conte, C.; Patria, F.; Cataldi, S.; Bertelli , M.; Albi, E.; Beccari, T. Alpha-mannosidosis: therapeutic strategies. Int. J. Mol. Sci. 2018, 19, 1500.

4. Bruggink, C.; Ben J. H. M. Poorthuis, B. J. H. M.; Deelder, A. M.; Wuhrer, M. Analysis of urinary oligosaccharides in lysosomal storage disorders by capillary high-performance anionexchange chromatography-mass spectrometry. Anal. Bioanal. Chem. 2012, 403, 1671-1683.

5. Egge, H.; Michalski, J. C.; Strecker, G. Heterogeneity of urinary oligosaccharides from mannosidosis: mass spectrometric analysis of permethylated Man9, Man8, and Man7 derivatives. Arch. Biochem. Biophys. 1982, 213, 318-326.

6. Autio S.; Louhimo, T.; Helenius, M. The clinical course of mannosidosis. Ann. Clin. Res. 1982, 14, 93-97.

7. Malm, D.; Nilssen, Ø. Alpha-mannosidosis. Orphanet J. Rare Dis. 2008, 3, 21.

8. Mynarek, M.; Tolar, J.; Albert, M. H.; Escolar, M. L.; Boelens, J. J.; Cowan, M.J.; Finnegan, N.; Glomstein, A.; Jacobsohn, D.A.; Kühl, J.S.; Yabe, H.; Kurtzberg, J.; Malm, D.; Orchard, P. J.; Klein, C.; Lücke, T.; Sykora, K. W. Allogeneic hematopoietic SCT for alpha-mannosidosis: An analysis of 17 patients. Bone Marrow Transpl. 2012, 47, 352-359.

9. Solomon, M.; Muro, S. Lysosomal enzyme replacement therapies: Historical development, clinical outcomes, and future perspectives. Adv. Drug. Deliv. Rev. 2017, 118, 109-134.

10. Harmatz, P.; Cattaneo, F.; Ardigò, D.; Geraci, S.; Hennermann, J. B.; Guffon, N.; Lund, A.; Hendriksz, C. J.; Borgwardt, L. Enzyme replacement therapy with velmanase alfa (human recombinant alpha-mannosidase): Novel global treatment response model and outcomes in patients with alpha-mannosidosis. Mol. Genet. Metab. 2018, 124, 152-160. 
11. Lund, A. M.; Borgwardt, L.; Cattaneo, F.; Ardigò, D.; Geraci, S.; Gil-Campos, M.; De Meirleir, L. ; Laroche, C. ; Dolhem, P.; Cole, D.; Tylki-Szymanska, A.; Lopez-Rodriguez, M.; GuillénNavarro, E.; Dali, C. I.; Héron, B.; Fogh, J.; Muschol, N.; Phillips, D.; Van den Hout, J. M. H.; Jones, S. A.; Amraoui, Y.; Harmatz, P.; Guffon, N. Comprehensive long-term efficacy and safety of recombinant human alpha-mannosidase (velmanase alfa) treatment in patients with alphamannosidosis. J. Inherit. Metab. Dis. 2018, 41, 1215-1223.

12. Hansen, G.; Berg, T.; Stensland, H. M. F. R.; Heikinheimo, P.; Klenow, H.; Evjen, G.; Nilssen, $\emptyset . ;$ Tollersrud, O. K. Intracellular transport of human lysosomal $\alpha$-mannosidase and $\alpha$ mannosidosis-related mutants. Biochem. J. 2004, 381, 537-546.

13. Pereira, D. M.; Valentao, P.; Andrade, P. B. Tuning protein folding in lysosomal storage diseases: the chemistry behind pharmacological chaperones. Chem. Sci. 2018, 9, 1740-1752.

14. Platt, F. M. Emptying the stores: lysosomal diseases and therapeutic strategies. Nat. Rev. Drug Discov. 2018, 17, 134-150.

15. Fedah E. Mohamed, F. E.; Al-Gazali, L.; Al-Jasmi, F.; Ali, B. R. Pharmaceutical chaperones and proteostasis regulators in the therapy of lysosomal storage disorders: current perspective and future promises. Front. Pharmacol. 2017, 8, 448.

16. Parenti, G.; Andria, G.; Valenzano, K. J. Pharmacological chaperone therapy: preclinical development, clinical translation, and prospects for the treatment of lysosomal storage disorders. Mol. Ther. 2015, 23, 1138-1148.

17. Boyd, R. E.; Lee, G.; Rybczynski, P.; Benjamin, E. R.; Khanna, R.; Wustman, B. A.; Valenzano, K. J. Pharmacological chaperones as therapeutics for lysosomal storage diseases. J. Med. Chem. 2013, 56, 2705-2730. 
18. Sánchez Fernández, E. M.; García Fernández, J. M.; Ortiz Mellet, C. Glycomimetic-based pharmacological chaperones for lysosomal storage disorders: Lessons from Gaucher, $\mathrm{GM}_{1-}$ gangliosidosis and Fabry diseases. Chem. Commun. 2016, 52, 5497-5515.

19. Stütz, A. E.; Wrodnigg, T. M. Carbohydrate-processing enzymes of the Lysosome: diseases caused by misfolded mutants and sugar mimetics as correcting pharmacological chaperones. Adv. Carbohydr. Chem. Biochem. 2016, 73, 225-302.

20. Zheng, J.; Chen, L.; Schwake, M.; Silverman, R. B.; Krainc, D. Design and synthesis of potent quinazolines as selective $\beta$-glucocerebrosidase modulators. J. Med. Chem. 2016, 59, 85088520.

21. García-Moreno, M. I.; de la Mata, M.; Sánchez-Fernández, E. M.; Benito, J. M.; DíazQuintana, A.; Fustero, S.; Nanba, E.; Higaki, K.; Sánchez-Alcázar, J. A.; García Fernández, J. M.; Ortiz Mellet, $C$. Fluorinated chaperone- $\beta$-cyclodextrin formulations for $\beta$-glucocerebrosidase activity enhancement in neuronopathic Gaucher disease. J. Med. Chem. 2017, 60, 1829-1842. 22. Kato, A.; Nakagome, I.; Nakagawa, S.; Kinami, K.; Adachi, I.; F. Jenkinson, S. F.; Désiré, J.; Blériot, Y.; Nash, R. J.; Fleet, G. W. J.; Hirono, S. In silico analyses of essential interactions of iminosugars with the Hex A active site and evaluation of their pharmacological chaperone effects for Tay-Sachs disease. Org. Biomol. Chem. 2017, 15, 9297-9304.

23. Front, S.; Almeida, S.; Zoete, V.; Charollais-Thoenig J.; Gallienne, E.; Marmy, C., Pilloud, V., Marti, R.; Wood, T., Martin, O. R.; Demotz, S. 4-epi-Isofagomine derivatives as pharmacological chaperones for the treatment of lysosomal diseases linked to $\beta$-galactosidase mutations: Improved synthesis and biological investigations. Bioorg. Med. Chem. 2018, 26, 5462-5469. 24. Moran, N. FDA approves Galafold, a triumph for Amicus. Nat. Biotechnol. 2018, 36, 913. 25. Flick, A. C.; Ding, H. X.; Leverett, C. A.; J. Fink, S. J.; O'Donnell, C. J. Synthetic approaches to new drugs approved during 2016. J. Med. Chem. 2018, 61, 7004-7031. 
26. Markham, A. Migalastat: first global approval. Drugs 2016, 76, 1147-1142.

27. D’Alonzo, D.; De Fenza, M.; Porto, C.; lacono, Huebecker, R. M.; Cobucci-Ponzano, B.;

Priestman, D. A.; Platt, F.; Parenti, G.; Moracci, M.; Palumbo, G.; Guaragna, A. N-Butyl-Ldeoxynojirimycin (L-NBDNJ): Synthesis of an allosteric enhancer of $\alpha$-glucosidase activity for the treatment of Pompe disease. J. Med. Chem. 2017, 60, 9462-9469.

28. Citro, V.; Peña-García, J.; den-Haan, H.; Pérez-Sánchez, H.; Del Prete, R.; Liguori, L.; Cimmaruta, C.; Lukas, J.; Cubellis, M. V.; Andreotti, G. Identification of an allosteric binding site on human lysosomal alpha-galactosidase opens the way to new pharmacological chaperones for Fabry disease. PLOS ONE 2016, 11, e0165463.

29. Berardi, A. S.; Pannuzzo, G.; Graziano, A.; Costantino-Ceccarini, E.; Piomboni, P.; Luddi, A. Pharmacological chaperones increase residual $\beta$-galactocerebrosidase activity in fibroblasts from Krabbe patients. Mol. Genet. Metab. 2014, 112, 294-301.

30. Porto, C.; Ferrara, M. C.; Meli, M.; Acampora, E.; Avolio, V.; Rosa, M.; Cobucci-Ponzano, B.; Colombo, G.; Moracci, M.; Andria, G.; Parenti, G. Pharmacological enhancement of $\alpha$ glucosidase by the allosteric chaperone N-acetylcysteine. Mol. Ther. 2012, 20, 2201-2211.

31. Mena-Barragán, T.; García-Moreno, M. I.; Alen Sevšek , A.; Okazaki, T.; Nanba, E.; Higaki, K.; Martin, N. I.; Pieters, R. J.; García Fernández, J. M.; Ortiz Mellet, C. Probing the inhibitor versus chaperone properties of $s^{2}$-Iminosugars towards human $\beta$-glucocerebrosidase: a picomolar chaperone for Gaucher disease. Molecules 2018, 23, 927.

32. Takai, T.; Higaki, K.; Aguilar-Moncayo, M.; Mena-Barragán, T.; Hirano, Y.; Yura, K.; Yu, L.; Ninomiya, H.; García-Moreno, M. I.; Sakakibara, Y.; Ohno, K.; Nanba, E.; Ortiz Mellet, C.; García Fernández, J. M.; Suzuki, Y. A bicyclic 1-deoxygalactonojirimycin derivative as a novel pharmacological chaperone for $\mathrm{G}_{\mathrm{M} 1}$ gangliosidosis. Mol. Ther. 2013, 21, 526-532. 
33. Cantarel, B.L.; Coutinho, P.M.; Rancurel, C.; Bernard, T.; Lombard, V.; Henrissat, B. The Carbohydrate-Active enZymes database (CAZy): An expert resource for glycogenomics. Nucleic Acids Res. 2009, 37, D233-D238.

34. Kuokkanen, E.; Stensland, H. M. F. R.; Smith, W.; Buvang, E. K.; Van Nguyen, L.; Nilssen, Ø.; Heikinheimo, P. Molecular and cellular characterization of novel $\alpha$-mannosidosis mutations. Human Mol. Genet. 2011, 20, 2651-2661.

35. Chotai, K.; Jennings, C.; Winchester, B.; Dorling, P. The uptake of swainsonine, a specific inhibitor of $\alpha$-mannosidase, into normal human fibroblasts in culture. J. Cell Biochem. 1983, 21, 107-117.

36. Kuntz, D. A.; Nakayama, S.; Shea, K.; Hori, H.; Uto, Y.; Nagasawa, H.; Rose, D. R. Structural investigation of the binding of 5-substituted swainsonine analogues to Golgi $\alpha$-mannosidase II. ChemBioChem 2010, 11, 673-680.

37. Safár, P.; Zúziová, J.; Marchalín, S.; Prónayová, N.; Svorc, L.; Vrábel, V.; Sesták, S.; Rendic, D.; Tognetti, V.; Joubert, L.; Daïch, A. Combined chemical, biological and theoretical DFTQTAIM study of potent glycosidase inhibitors based on quaternary indolizinium salts. Eur. J. Org. Chem. 2012, 5498-5514.

38. Poláková, M.; Sesták, S.; Lattová, E.; Petrus, L.; Mucha, J.; Tvaroska, I.; Kóna, J. $\alpha$-DMannose derivatives as models designed for selective inhibition of Golgi $\alpha$-mannosidase II. Eur. J. Med. Chem. 2011, 944-952.

39. Bella, M.; Sesták, S.; Moncol, J.; Koós, M.; Poláková, M. Synthesis of 1,4-imino-L-lyxitols modified at C-5 and their evaluation as inhibitors of GH38 $\alpha$-mannosidases. Beilstein J. Org. Chem. 2018, 14, 2156-2162. 
40. Kato, A.; Kato, N.; Kano, E.; Adachi, I.; Ikeda, K.; Yu, L.; Okamoto, T.; Banba, Y.; Ouchi, H.; Takahata, H.; Asano, N. Biological properties of D- and L-1-deoxyazasugars J. Med. Chem. 2005, 48, 2036-2044.

41. Díaz Pérez, P.; García-Moreno, M. I.; Ortiz Mellet, C.; García Fernández, J. M. Synthesis and comparative glycosidase inhibitory properties of reducing castanospermine analogues. Eur. J. Org. Chem. 2005, 2903-2913.

42. Luan, Z.; Higaki, K.; Aguilar-Moncayo, M.; Li, L.; Ninomiya, H.; Nanba, E.; Ohno, K.; GarcíaMoreno, M. I.; Ortiz Mellet, C.; García Fernández, J. M.; Suzuki, Y. Fluorescent sp²-iminosugar with pharmacological chaperone activity for Gaucher disease: synthesis and intracellular distribution studies. ChemBioChem 2010, 11, 2453-2464.

43. Sánchez-Fernández, E. M.; Rísquez-Cuadro, R.; Aguilar-Moncayo, M; García-Moreno, M. I.; Ortiz Mellet, C.; García Fernández, J. M. Generalized anomeric effect in gem-diamines: stereoselective synthesis of $\alpha-N$-linked disaccharide mimics. Org. Lett. 2009, 11, 3306-3309. 44. Sánchez-Fernández, E. M.; Gonçalves-Pereira, R.; Rísquez-Cuadro, R.; Plata, G. B.; Padrón, J. M.; García Fernández, J. M.; Ortiz Mellet, C. Influence of the configurational pattern of $\mathrm{sp}^{2}$ iminosugar pseudo $\mathrm{N}-, \mathrm{S}-, \mathrm{O}$ - and $\mathrm{C}$-glycosides on their glycoside inhibitory and antitumor properties. Carbohydr. Res. 2016, 429, 113-122.

45. Castilla, J.; Rísquez, R.; Cruz, D.; Higaki, K.; Nanba, E.; Ohno, K.; Suzuki, Y.; Díaz, Y.; Ortiz Mellet, C.; García Fernández, J. M.; Castillón, S. Conformationally-locked N-glycosides with selective $\beta$-glucosidase inhibitory activity: identification of a new noniminosugar-type pharmacological chaperone for Gaucher disease. J. Med. Chem. 2012, 55, 6857-6865. 46. Ortiz Mellet, C.; Nierengarten, J.-F.; García Fernández, J. M. Multivalency as an action principle in multimodal lectin recognition and glycosidase inhibition: a paradigm shift driven by carbon-based glyconanomaterials. J. Mater. Chem. B 2017, 5, 6428-6436. 
47. Diot, J.; García-Moreno, M. I.; Gouin, S. G.; Ortiz Mellet, C.; Haupt, K.; Kovensky, J. Multivalent iminosugars to modulate affinity and selectivity for glycosidases. Org. Bimol. Chem. 2009, 7, 357-363.

48. Brissonnet, Y.; Ortiz Mellet, C.; Morandat, S.; Garcia Moreno, M. I.; Deniaud, D.; Matthews, S. E.; Vidal, S.; Šesták, DS.; Kirat, K. E.; G. Gouin, S. G. Topological effects and binding modes operating with multivalent iminosugar-based glycoclusters and mannosidases. J. Am. Chem. Soc. 2013, 135, 18427-18435.

49. Lepage, M. L.; Schneider, J. P.; Bodlenner, A.; Meli, A.; De Riccardis, F.; Schmitt, M.; Tarnus, C.; Nguyen-Huynh, N.-T.; Francois, Y.-N.; Leize-Wagner, E.; Birck, C.; Cousido-Siah, A.; Podjarny, A.; Izzo, I.; Compain, P. Iminosugar-cyclopeptoid conjugates raise multivalent effect in glycosidasei at unprecedented high levels. Chem. Eur. J. 2016, 22, 5151-5155.

50. Howard, E.; Cousido-Siah, A.; Lepage, M. L.; Schneider, J. P.; Bodlenner, A.; Mitschler, A.; Meli, A.; Izzo, I.; Alvarez, A.; Podjarny, A.; Compain, P. Structural basis of outstanding multivalent effects in Jack bean $\alpha$-mannosidase inhibition. Angew. Chem. Int. Ed. 2018, 57, $8002-8006$

51. Mirabella, S.; D’Adamio, G.; Matassini, C.; Goti, A.; Delgado, S.; Gimeno, A.; Robina, I.; Moreno-Vargas, A. J.; Sesták, S.; Jiménez-Barbero, J.; Cardona, F. Mechanistic insight into the binding of multivalent pyrrolidines to $\alpha$-mannosidases. Chem. Eur. J. 2017, 23, 14585-14596.

52. Rísquez-Cuadro, R.; García Fernández, J. M.; Nierengarten, J.-F.; Ortiz Mellet, C. Fullerene$\mathrm{sp}^{2}$-iminosugar balls as multimodal ligands for lectins and glycosidases: A mechanistic hypothesis for the inhibitory multivalent effect. Chem. Eur. J. 2013, 19, 16791-16803.

53. François-Heude, M. Méndez-Ardoy, A.; Cendret, V.; Lafite, F.; Daniellou, R.; Ortiz Mellet, C.; García Fernández, J. M.; Moreau, V.; Djedaïni-Pilard, F. Synthesis of high-mannose 
oligosaccharide analogues through click: true functional mimics of their natural counterparts against lectins? Chem. Eur. J. 2015, 21, 1978-1991.

54. Crini, G. Review: a history of cyclodextrins. Chem. Rev. 2014, 114, 10940-10975.

55. García-Moreno, M. I.; Ortega-Caballero, F.; Rísquez-Cuadro, R.; Ortiz Mellet, C.; García Fernández, J. M. The impact of heteromultivalency in lectin recognition and glycosidase inhibition: an integrated mechanistic study. Chem. Eur. J. 2017, 23, 6295-6304.

56. Siriwardena, A.; Khanal, M.; Barras, A.; Bande, O.; Mena-Barragan, T.; Ortiz Mellet, C.; Garcia Fernandez, J. M.; Boukherroub, R.; Szunerits, S. Unprecedented inhibition of glycosidase-catalyzed substrate hydrolysis by nanodiamond-grafted O-glycosides. RSC Adv. 2015, 5, 100568-100578.

57. Abellán Flos, M.; García Moreno, M. I.; Ortiz Mellet, C.; García Fernández, J. M.; Nierengarten, J.-F.; Vincent, S. P. Potent glycosidase inhibition with heterovalent fullerenes: unveiling the binding modes triggering multivalent inhibition. Chem. Eur. J. 2016, 22, 1145011460.

58. Hamayasu, K.; Hara, K.; Fujita, K.; Kondo, Y.; Hashimoto, H.; Tanimoto, T.; Koizumi, K.; Nakano, H.; Kitahata, S. Enzymatic synthesis of mannosyl-cyclodextrin by ex-mannosidase from jack bean. Biosci. Biotech. Biochem. 1997, 61, 825-829.

59. Koizumi, K.; Tanimoto, T.; Okada, Y.; Takeyama, S.; Hamayasu, K.; Hashimoto, H.; Kitahata, S. Isolation and characterization of di- and tri-mannosyl-cyclomaltoheptaoses ( $\beta$-cyclodextrins) produced by reverse action of $\alpha$-mannosidase from jack bean. Carbohydr. Res. 1998, 314, 115125.

60. Alvarez-Dorta, D.; Brissonnet, Y.; Saumonneau, A.; Deniaud, D.; Bernard, J. Xibo Yan, X.; Tellier, C.; Daligault, F.; Gouin, S. G. Magnetic nanoparticles coated with thiomannosides or iminosugars to switch and recycle galactosidase activity. ChemistrySelect 2017, 2, 9552-9556. 
61. Vembar, S. S.; Brodsky, J. L. One step at a time: endoplasmic reticulum-associated degradation. Nat. Rev. Mol. Cell Biol. 2008, 9, 944-957.

62. Johnson, W. G. Disorders of glycoprotein degradation: sialidosis, fucosidosis, $\alpha-$ mannosidosis, $\beta$-mannosidosis, and aspartylglycosaminuria. In Rosenberg's Molecular and Genetic Basis of Neurological and Psychiatric Disease, 5th ed.; Rosenberg, R. N., Pascual, J. M., Eds. Elsevier: San Diego, 2014; chapter 33, pp 369-383.

63. Stensland, H. M. F. R.; Frantzen, G.; Kuokkanen, E.; Buvang, E. K.; Klenow, H. B.; Heikinheimo, P.; Malm, D.; Nilssen, $\varnothing$. amamutdb.no: A relational database for MAN2B1 allelic variants that compiles genotypes, clinical phenotypes, and biochemical and structural data of mutant MAN2B1 in $\alpha$-mannosidosis. Human Mut. 2015, 36, 581-586.

64. Walkley, S. U.; Vanier, M. T. Secondary lipid accumulation in lysosomal disease. Biochim. Biophys. Acta 2009, 1793, 726-736.

65. Damme, M.; Stroobants, S.; Walkley, S. U.; Lüllmann-Rauch, R.; D’Hooge, R.; Fogh, J.; Saftig, P.; Lübke, T.; Blanz, J. Cerebellar alterations and gait defects as therapeutic outcome measures for enzyme replacement therapy in $\alpha$-mannosidosis. J. Neuropathol. Exp. Neurol. 2011, 70, 8394. 66. Decroocq, C.; Rodríguez-Lucena, D.; Ikeda, K.; Asano, N.; Compain, P. Cyclodextrin-based iminosugar click clusters: the first examples of multivalent pharmacological chaperones for the treatment of lysosomal storage disorders. ChemBioChem 2012, 13, 661-664.

67. Joosten, A.; Decroocq, C.; de Sousa, J.; Schneider, J. P.; Etamé, E.; Bodlenner, A.; Butters, T. D.; Compain, P. A systematic investigation of iminosugar click clusters as pharmacological chaperones for the treatment of Gaucher disease. ChemBioChem 2014, 15, 309-319.

68. Laigre, E.; Hazelard, D.; Casas, J.; Serra-Vinardell, J.; Michelakakis, H.; Mavridou, I.; Aerts, J. M. F. G.; Delgado, A.; Compain, P. Investigation of original multivalent iminosugars as 
pharmacological chaperones for the treatment of Gaucher disease. Carbohydr. Res. 2016, 429, 98-104.

69. Mu, T.-W.; Fowler, D. M.; Kelly, J. W. Partial restoration of mutant enzyme homeostasis in three distinct lysosomal storage disease cell lines by altering calcium homeostasis. PLOS Biol. 2008, 6, e26.

70. Sánchez Fernández, E. M.; Álvarez, E.; Ortiz Mellet, C.; García Fernández, J. M. Synthesis of Multibranched Australine Derivatives from reducing castanospermine analogues through the Amadori rearrangement of gem-diamine Intermediates: selective inhibitors of $\beta$-glucosidase. J. Org. Chem. 2014, 79, 11722-11728.

71. Faiz, J. A.; Spencer, N.; Pikramenou, Z. Acetylenic cyclodextrins for multireceptor architectures: cups with sticky ends for the formation of extension wires and junctions. Org. Biomol.Chem., 2005, 3, 4239-4245.

72. Calvo-Flores, F. G.; Isac-García, J.; Hernandez-Mateo, F.; Perez- Balderas, F. ; Calvo-Asín, A. ; Sanchez-Vaquero, J. ; Santoyo-Gonzalez, F. 1,3-Dipolar cycloadditions as a tool for the preparation of multivalent structures. Org. Lett., 2000, 2, 2499-2502.

73. Kaya, E.; Gutsmiedl, K.; Vrabel, M.; Müller, M.; Thumbs, P.; Carell, T. Synthesis of threefold glycosylated proteins using click Chemistry and genetically encoded unnatural amino acids. ChemBioChem, 2009, 10, 2858-2861.

74. Sterling, T.; J. Irwin, J. J. ZINC 15 - Ligand discovery for everyone. J. Chem. Inf. Model. 2015, $55,2324-2337$.

75. Higaki, K.; Li, L.; Bahrudin, U.; Okuzawa, S.; Takamuram, A.; Yamamoto, K.; Adachi, K.; Paraguison, R. C.; Takai, T.; Ikehata, H.; Tominaga, L.; Hisatome, I.; lida, M.; Ogawa, S.; Matsuda, J.; Ninomiya, H.; Sakakibara, Y.; Ohno, K.; Suzuki, Y.; Nanba, E. Chemical chaperone 
therapy: chaperone effect on mutant enzyme and cellular pathophysiology in $\beta$-galactosidase deficiency. Hum. Mutat. 2011, 32, 843-852.

76. Takamura, A.; Higaki, K.; Ninomiya, H.; Takai, T.; Matsuda, J.; lida, M.; Ohno, K.; Suzuki, Y.; Nanba, E. Lysosomal accumulation of Trk protein in brain of G(M1)-gangliosidosis mouse and its restoration by chemical chaperone. J. Neurochem. 2011, 118, 399-406. 
Table of Contents graphic

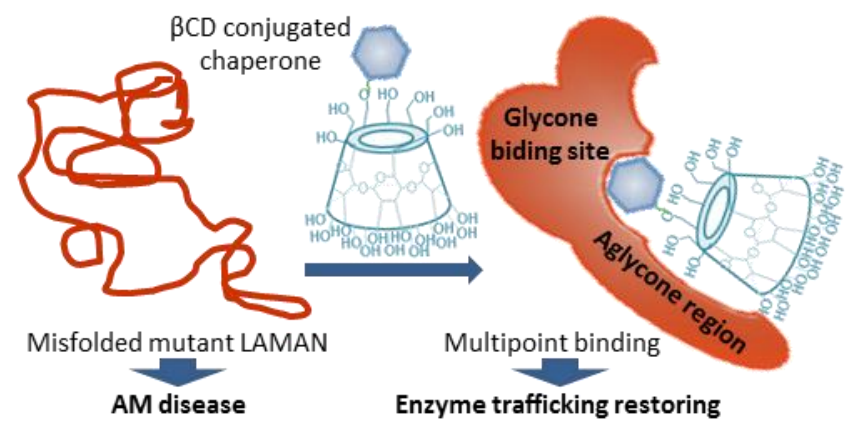

